\title{
MAPEAMENTO DA COLHEITA MECANIZADA DE GRÃOS UTILIZANDO UM SISTEMA DE POSICIONAMENTO GLOBAL
}

\author{
ALEXANDRE ISMAEL ELIAS
}

Engenheiro Agrônomo

Orientador: Prof. Dr. LUIZ ANTONIO BALASTREIRE

Dissertaçăo apresentada à Escola Superior de Agricultura "Luiz de Queiroz", Universidade de São Paulo, para obtençăo do título de Mestre em Agronomia, Área de Concentração: Máquinas Agrícolas.

PIRACICABA

Estado de São Paulo - Brasil

Dezembro - 1998 
Errata

No texto:

Onde se lê

Leia-se

Blackmore et. al. (1996) Blackmore \& Marshall (1996)

Evans et al. (1994a) Evans \& Han (1994a)

Evans et al. (1994b) Evans \& Han (1994b)

et. al.

et al.

treliças

taliscas

Kincheloe (1994)

Kincheloe (1991)

Na Tabela 1

(GPS)

(DGPS)

Página i, Figura 9

Curva de calibração Equação de calibração

Página ii, Tabela 5

Página 50

Retire-se Tabela 5 referente à página 51

$$
\begin{array}{cc}
Y_{1 b}=\frac{Y_{1}}{d_{1}} \times d_{1 b} & Y_{1 b}=Y_{1} \times d_{1 b} \\
Y_{2 b}=\frac{Y_{2}}{d_{2}} \times d_{2 b} & Y_{2 b}=Y_{2} \times d_{2 b} \\
\text { sem a utilização } & \text { com a utilização } \\
\text { SAUNDERS, S.P., } & \text { Retire-se a citação } \\
\text { SCHUELLER, J.L,, } & \text { Retire-se a citação }
\end{array}
$$

Página 54, Tabela 7

Página 74

Página 74 
Dados Internacionais de Catalogaçāo na Publicaçāo (CIP)

DIVISÃo DE BIBLIOTECA E DOCUMENTAÇÃO - Campus "Luiz de Queiroz"/USP

Elias, Alexandre Ismael

Mapeamento da colheita mecanizada de grãos utilizando um sistema de posicionamento global / Alexandre Ismael Elias. - Piracicaba, 1998.

$75 \mathrm{p}$.

Dissertação (mestrado) - Escola Superior de Agricultura Luiz de Queiroz, 1998. Bibliografia.

1. Agricultura de precisão 2. Colheita mecânica 3. GPS (Sistema de computador) , 4. Mapeamento 5. Produtividade agricola 1. Titulo

CDD 631.35 


\section{DEDICATÓRIA}

A meus pais, Carlos Gothardi Elias (in memorian) e Dinorá Ismael Elias, minha irmã Samira Ismael Elias e minha tia Jamile Ismael Martins, pelo apoio e incentivo a mim confiados.

A minha esposa, Lilian Cristina Casagrande Elias, dedico. 


\section{AGRADECIMENTOS}

Ao Departamento de Engenharia Rural (DER) da Escola Superior de Agricultura "Luiz de Queiroz" - ESALQ/USP pela oportunidade a mim concedida.

Ao Prof. Dr. Luiz Antonio Balastreire, pela orientação na condução deste trabalho.

Ao setor de Topografia e Sensoriamento Remoto do DER, nas pessoas dos professores Rubens Angulo Filho, Carlos A. Vetorazzi, pelo apoio e incentivo prestados, os quais muito contribuíram para a elaboração deste trabalho.

Ao Eng. Juarez Renó Amaral e Adilson Rodrigues pelo constante e indispensável auxilio na condução deste trabalho.

Aos colegas Rogério C. Bernardes, e Fábio Baio, pelo auxilio e participação neste trabalho.

Ao Prof. Marcos Milan, em especial pela amizade, confiança e incentivo a mim confiados.

A CAPES pela bolsa concedida durante o período de execução deste trabalho.

A Fazenda Areão, nas pessoas do Eng. Luiz Fernando e Alberto, pelo auxílio e atenção dispensadas.

A todos que, direta e indiretamente, contribuíram para a elaboração, condução e conclusão deste trabalho. 


\section{SUMÁRIO}

Págìna

LISTA DE FIGURAS

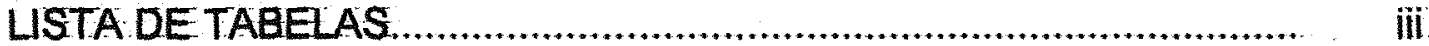

RESUMO

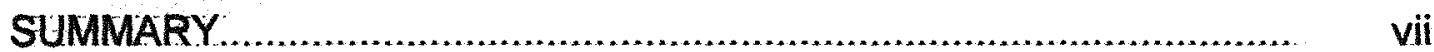

1. INTRODUÇÃO

2. REVISÃO DE LITERATURA

2.1. Agricultura de precisăo

21.1. Conceitos básicos da agricultura de precisấo ............................. 7

2:1.2. Exigências para a implantação da agricultura de precisăo........ $\quad 10$

2.1.2. Subdivisão da área en células ............................................ 11

2.1.2.2. Sistemas de posicionamento ................................................ 12

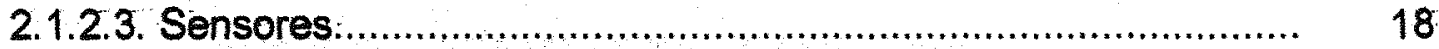

2.1.2.4. Sistemas de informaçőes geográficas-SIG ......................... 19

2.1.3. Etapas e operaçőes que compöem a agricultura de precisão... $\quad 20$

2.1.3.1. Aquisição $e$ análise de dados................................................. 22

2.1.3.2. Interpretação dos resultados.................................................. 24

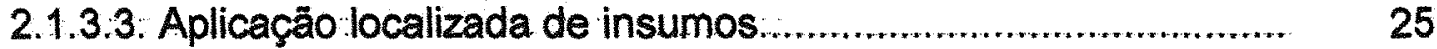

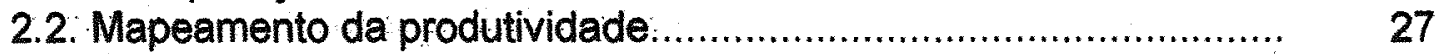

2.2.1. Tecnalogia necessária para o mapeamento da produtividade.... 27

2.2.2. Equipamentos e metodologias utilizadas produtividade $\ldots . \ldots . . . . . .29$

2.2.3. Fontes de erros existentes no mapeamento da produtividade.... $\quad 34$

3. MATERIAL E.MÉTODOS

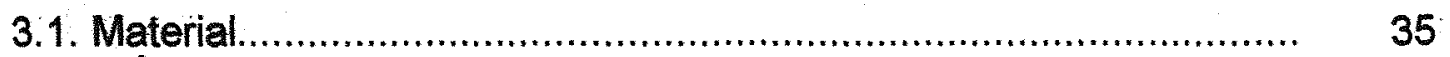

3.1.1. Area e cultura ................................................................. 35

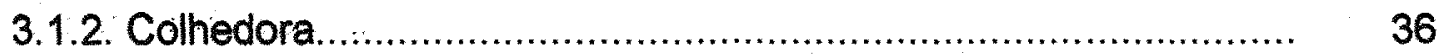

3.1.3. Sistema automático de medição da produtividade ...................... 37

3.1.4. Sistema de posicionamento global utilizado-GPS ................. 38

3.1.5. Sistema de aquisiçăo de dados .................................................. 39 


\section{SUMÁRIO}

3.2. Métodos.............................................................................. 40

3.2.1. Desenvolvimento, montagem e calibração do sistema de medição da produtividade.

3.2.2. Configuração do sistema de posicionamento global..................... 43

3.2.3. Verificação da acurácia do sistema de GPS utilizado................. 44

3.2.4. Correção diferencial de posição................................................ 45

3.2.5. Correção de posicionamento em função do tempo de processamento do material colhido (grãos).............................. 46

3.2.6. Divisão da área em "células"............................................... 47

3.2.6.1. Determinação do ponto representativo e do centro das células 47

3.2.6.2. Cálculo da produtividade ...................................................... 49

4. RESULTADOS E DISCUSSÃO ................................................... 51

4.1. Sistema de medição da produtividade - calibração estática.......... 51

4.2. Sistema de medição da produtividade - calibração dinâmica........ 53

4.3. Dados de posição e peso ......................................................... 56

4.4. Acurácia do sistema de GPS.................................................. 57

4.5. Posicionamento da colhedora.................................................... 60

4.6. Peso acumulado de grãos............................................................ 62

4.7. Mapeamento da produtividade da cultura...................................... 63

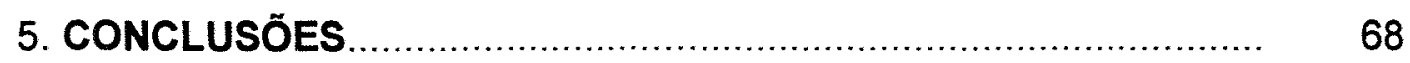

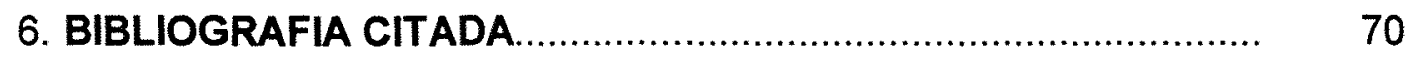




\section{LISTA DE FIGURAS}

Figura 1. Produtividade da cultura em função do tipo de solo e do nível de fertilidade considerado.

Página

Figura 2. Ciclo da agricultura de precisão. A interação dos quatro subsistemas essenciais dispostos em três etapas básicas.

Figura 3. Representação gráfica do fluxo de dados característico da agricultura de precisão.

Figura 4. Representação esquemática (croqui) da área utilizada para o trabalho.

Figura 5. Sistema de monitoramento da produtividade desenvolvido: Esquema de montagem do sub-tanque fixado no interior do tanque graneleiro da colhedora Massey Fergusson modelo 6845 utilizada.

Figura 6.

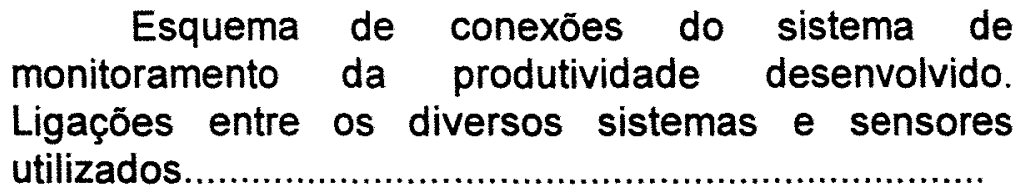

Figura 7. Representação gráfica ilustrativa da célula, apresentando a metodologia para a determinação do "ponto representativo" $\left(P_{r}\right)$

Figura 8.

Figura 9.

Curva de calibraçào obtida para o sistema de medição da produtividade. Sistema em regime de carregamento. 
Figura 10. Valores de erro absoluto médio obtidos nos ensaios dinâmicos do sistema de medição da produtividade com e sem a filtragem digital dos dados..

Figura 11. Dispersão dos pontos obtidos pelo GPS............. 60

Figura 12. Representação gráfica das coordenadas geográficas, longitude e latitude, coletadas durante a operação de colheita para o talhão 1 . Verificação da eficácia da correção diferencial de posição dos dados fornecidos pelo GPS

Figura 13

Peso acumulado no interior do sub-tanque graneleiro em função da distância percorrida pela colhedora. Peso médio obtido em intervalos constantes de 10,8 metros.

Figura 14

$$
\text { Mapa de produtividade da cultura do milho...... }
$$

Figura 15

Distribuição da produtividade da cultura do milho para a área mapeada.

Figura 16

Mapa de isoprodutividade obtido para a cultura do milho. 


\section{LISTA DE TABELAS}

Página

Tabela 1. Influência das principais fontes de erros assiciadas aos sistemas de posicionamento global com (DGPS) e sem (GPS) correção diferencial.

Tabela 2. Necessidade de acurácia do sistema de posicionamento em função de diferentes operações em campo

Tabela 3. Principais fontes de erros associadas ao sistema GPS de posicionamento.

Tabela 4.

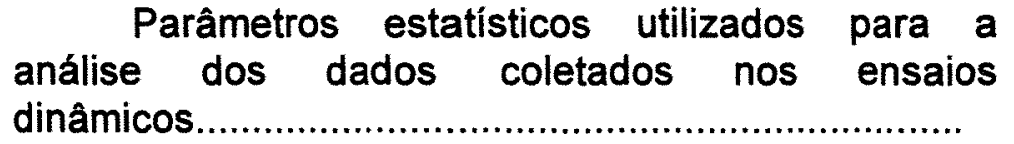

Tabela 5. Parâmetros de configuração da porta serial (padrão RS-232) do conversor analógico digital..........

Tabela 5. Resultados obtidos no ensaio de calibração estática realizado para o sistema de medição da produtividade desenvolvido. Equações de calibração obtidas para as condições de carregamento e descarregamento

Tabela 6.

Análise estatística para o ensaio dinâmico do sistema de medição da produtividade sem a utilização da filtragem digital....

Tabela 7.

Análise estatística para o ensaio dinâmico do sistema de medição da produtividade com a utilização da filtragem digital. 


\section{LISTA DE TABELAS}

Tabela 8. Estrutura dos arquivos de dados após correção diferencial e transformação para padrão ASCII

Tabela 9. Coordenadas geográficas determinadas através de método convencional de topografia, com a utilização de distanciômetro eletrônico e através de GPS

Tabela 10. Comparação das distâncias (m) entre posições individuais indicadas pelo GPS e a respectiva posição média do ponto

Tabela 11. Comparação das distâncias (m) entre posições individuais indicadas pelo GPS e a respectiva posição real, obtida com distanciômetro eletrônico por métodos topográficos convencionais.

Tabela 12 Dados de posição e produtividade calculados para cada uma das células, a partir dos quais foram elaborados os mapas de produtividade.

Tabela 13. Intervalos de produtividade considerados para a elaboração do mapa de produtividade. 


\section{RESUMO}

Elevadas produtividades na produção de grãos têm sido obtidas principalmente com a utilização de grandes quantidades de insumos químicos. Os principais problemas da utilização de super dosagens destes produtos estão relacionadas à poluição ambiental e ao aumento dos custos de produção agrícola. Na busca pela melhoria da eficiência do processo produtivo agrícola, do aumento da produtividade, redução dos custos de produção e principalmente na minimização do impacto ambiental, novas tecnologias estão surgindo. O maior e mais importante exemplo refere-se à agricultura de precisão, a qual tem sido considerada por vários autores como a mais promissora ferramenta disponivel aos agricultores.

A agricultura de precisão está fortemente baseada no conhecimento e gerenciamento da variabilidade espacial dos fatores de produção, sendo que o mapeamento da produtividade das culturas é considerado crucial e indispensável.

Este trabalho relata o desenvolvimento, construção e utilização de um sistema automático de pesagem de grãos utilizado para o mapeamento da produtividade, constituído de um sub-tanque graneleiro apoiado sobre quatro células de carga, montado no interior do tanque graneleiro de uma colhedora combinada, sem que nenhuma alteração estrutural tenha sido realizada. Um sistema de posicionamento global móvel foi utilizado na colhedora para o posicionamento geo-referenciado desta, sendo a correção diferencial realizada em pós processamento.

Os sistemas utilizados permitiram a realização do mapeamento da produtividade de uma área de aproximadamente 7 ha, subdividida em 
células de 10,8 metros de comprimento por 3,6 metros de largura. A produtividade média da área foi de 3,76 tha, sendo que $9,75 \%$ da área apresentou produtividade inferior a 2,41 tha e somente $0,54 \%$ da área apresentou produtividade superior a 5,94t/ha.

A principal vantagem da utilização do sistema automático de pesagem desenvolvido neste trabalho refere-se a possibilidade da obtenção direta do peso do material colhido, sem que haja necessidade da utilização de sensores para a determinação da umidade do material colhido. Outra vantagem refere-se a facilidade e simplicidade de calibração do sistema, a qual independe do tipo de grão, das características físicas e da umidade destes. O mesmo princípio de medição da produtividade poderá ser adaptado para o mapeamento da produtividade de outras culturas cujas características não permitam a utilização de sensores de fluxo de massa.

PALAVRAS CHAVES: Agricultura de precisão; Mapeamento da produtividade; Sensores; GPS; DGPS; Aquisição de dados. Células de carga. 


\section{SUMMARY}

High yield on crop production systems has been obtained mainly by of high chemical inputs. The major problems of this high amount of these inputs are related with environmental pollution and production costs improvement. New technologies to maximize the efficiency of inputs utilization has been created to improve yield crop, reduce production costs and environmental impact. The most important example of this new technologies is precision farming, which has been considered one of the most important tool available to farmers.

The precision farming technology is strongly based on knowledge and management of production factors spacial variability, and the crop yield mapping is considered crucial to precision farming.

This work describes the development, construction and use of a automatic weighing grain system used to yield mapping, which is composed by a sub-tank supported by four load cells and fixed into a combine grain tank, without any structural modifications. A global positioning systems was used to determine the geographical position of the combine, and the differential correction was done by post-processing.

The yield mapping was obtained for a 7 ha area divided into cells with 10,8 meters of length and 3,6 meters of width. The average yield was 3,76 tons/ha, but $9,75 \%$ of the area presented yield lower than 2,41 tons/ha and only $0,54 \%$ of the total area showed a yield greater than $5,94 \%$.

The main advantage of the automatic system developed is the possibility of direct measurement of the grain weight without flow sensors or moisture sensor. Another advantage of the system is that just one calibration 
must be executed and it isn't influenced by the grain type, physical characteristics and grain moisture. The same principle can be used to mapping the yield of other types of crops when the flow sensors can't be used.

KEY WORLD: Precision farming; Yield mapping; Sensors; GPS; DGPS; Data acquisition; Load cells. 


\section{INTRODUÇÃO.}

O aumento da demanda por alimentos, proporcionado principalmente pelo crescimento desenfreado da população mundial, é atualmente uma realidade. Como conseqüência direta do aumento desta demanda, o setor agro-industrial tem sido forçado a ampliar cada vez mais a quantidade de alimentos produzidos, principalmente de grãos, isto é, milho (Zea mays, L.), soja (Glycine $\max (\mathrm{L}$.) Merrill), feijão (Phaseolus vulgaris L.), trigo (Triticum spp), e outros. $O$ aumento da quantidade de grãos produzidos esteve fortemente baseado, até pouco tempo atrás, na expansão das fronteiras agrícolas, caracterizada pelo desbravamento de regiōes nunca antes utilizadas para a agricultura. A disponibilidade de áreas potencialmente agricultáveis, entretanto, têm diminuído consideravelmente nos últimos anos, exigindo assim que novas técnicas sejam aprimoradas e/ou desenvolvidas a fim de permitir o aumento da produção de grãos. Dentre estas novas técnicas, destaca-se a rotação de culturas, a qual além de representar grandes benefícios agronômicos, proporciona um melhor aproveitamento das áreas produtivas. $O$ incremento da produtividade das culturas, entretanto, é a forma mais importante e eficaz de se elevar a quantidade de grãos produzidos sem que novas áreas produtivas sejam utilizadas.

A busca desenfreada pelo aumento da produtividade fez crescer assustadoramente a utilização de insumos químicos, principalmente de fertilizantes e defensivos agrícolas. $O$ uso indiscriminado e descontrolado destes produtos veio acarretar inúmeros problemas agronômicos, financeiros

e principalmente ambientais. Sendo limitada a capacidade de aproveitamento das culturas, o excesso do insumo aplicado ao solo acaba 
sendo lixiviado elou levado pelas águas das chuvas, contaminando rios, lagos e lençóis freáticos. A eliminação de insetos benéficos, inimigos naturais de determinadas pragas, é um outro grave problema diretamente relacionado a utilização exacerbada destes produtos.

Além dos problemas ambientais e ecológicos decorrentes do uso "irracional" dos insumos químicos, as super dosagens utilizadas contribuem diretamente para o aumento dos custos de produção, visto que grande parte do material distribuído acaba sendo perdido.

Neste contexto, Auernhammer et. al. (1994) afirmam que o conflito entre a economia e a ecologia tem crescido continuamente, principalmente pelo fato do aumento da lucratividade do agricultor estar fortemente baseada no aumento da produtividade, a qual têm sido obtida principalmente através da utilização de dosagens cada vez maiores de fertilizantes e defensivos. Os autores destacaram ainda a importância da elaboração de um balanço entre a utilização dos fertilizantes por parte das plantas e as dosagens de fertilizantes a serem utilizadas, como forma de se evitar a utilização de quantidades supra-ótimas. Uma considerável melhoria neste balanço pode ser obtida se a variabilidade espacial das necessidades de adubação for considerada, sendo a condução e o gerenciamento da cultura realizados de forma localizada e específica.

Para a implementação de operações de campo realizadas de forma diferenciada e espacialmente variável ao longo da área, são necessários, segundo Stafford (1996b) quatro ações distintas, representadas por quatro sub-sistemas básicos:

1) Monitoramento do solo e da cultura;

2) Posicionamento dos conjuntos operacionais em campo;

3) Mapeamento da produtividade;

4) Mecanismos precisos de aplicação localizada de insumos e sementes com controle automático de dosagem.

De acordo com Balastreire (1994), o termo "aplicação localizada de insumos - ALI", pode ser utilizado como forma de caracterizar aplicações de 
insumos sobre pontos específicos da área e em quantidades variáveis, cujas coordenadas geográficas, latitude e longitude, sejam conhecidas.

De acordo com Kincheloe (1994), o objetivo do gerenciamento localizado é maximizar a eficiência do uso de todos os insumos, a fim de se obter elevadas produtividades associadas à máxima rentabilidade econômica. O gerenciamento localizado das culturas, também denominado agricultura de precisão, é visto pelo autor como uma das mais poderosas ferramentas de gerenciamento.

A elaboração deste trabalho justifica-se pela importância que o mapeamento da produtividade representa para a agricultura de precisão, considerada por vários autores como ferramental indispensável ao agricultor na busca da auto-sustentabilidade econômica e ecológica da atividade produtivida agrícola.

Neste contexto, o presente estudo tem como objetivos o desenvolvimento, construção, teste e utilização de um sistema automático de pesagem para o mapeamento da produtividade de culturas agrícolas. 


\section{REVISÃO DE LITERATURA.}

Muita ênfase e importância tem sido dada à agricultura de precisão ultimamente, a qual tem sido considerada a mais moderna e poderosa ferramenta à disposição da agricultura para o aumento da produtividade. É importante, entretanto, que todos os conceitos desta nova forma de gerenciamento sejam exaustivamente discutidos e entendidos, bem como as tecnologias necessárias. O estudo de seu "estado da arte", indispensável para a condução deste trabalho, é portanto apresentado a seguir.

\subsection{Agricultura de precisão.}

Kincheloe (1994) afirmou que os termos "práticas gerenciais otimizadas", "máxima produtividade econômica" e "agricultura sustentáver" são conceitos extremamente importantes para a agricultura, principalmente no contexto econômico atual. A utilização de processos otimizados de gerenciamento podem contribuir para elevação da produtividade das culturas. Através da utilização de técnicas otimizadas, o produtor pode aproveitar ao máximo o potencial produtivo da área cultivada e da cultura conduzida e melhorar o aproveitamento dos insumos, diminuindo assim os impactos ambientais decorrentes do uso excessivo destes e contribuir desta forma para se atingir a auto-sustentabilidade. Neste contexto, o autor deu grande ênfase à agricultura de precisão, caracterizando-a como um ferramental de grande potencial a ser utilizado pela agricultura para aumentar a eficiência da utilização dos insumos, minimizando os 
desperdícios e conseqüentemente diminuindo os custos de produção e os impactos ambientais.

De acordo com Goering (1992), a agricultura convencional está amplamente apoiada na pressuposição da homogeneidade das propriedades e características físicas, químicas e biológicas dos solos e das culturas. Embora a não veracidade de tais conceitos seja conhecida, tal pressuposição ainda é utilizada atualmente. Assim, para a análise química do solo, realizada para se determinar as condições da fertilidade, várias amostragens são realizadas ao longo da área considerada, sendo que os resultados obtidos são considerados representativos, aceitando-se assim a pressuposição que as recomendações realizadas com base nas amostras são ideais para toda a área. Assim, como extensão do conceito da homogeneidade, todas as operações realizadas com base na agricultura convencional baseiam-se no conceito da uniformidade, sendo a aplicação de qualquer insumo é realizada utilizando-se uma dosagem constante em toda uma área. Quanto mais uniforme for a aplicação, tanto maior a "qualidade" da operação.

Embora pareça uma grande incoerência, havia várias justificativas para a adoção da pressuposição de homogeneidade, conforme relataram Goering \& Han (1993). Devido a não existência de tecnologia especializada capaz de determinar, localizar e quantificar as variações espaciais dos fatores de produção, assim como a incapacidade da realização de operações de aplicação localizada e em dosagens variáveis de insumos, não havia justificativas agronômica e econômica para que fossem identificadas tais variações. Por este motivo, embora a existência da variabilidade espacial dos fatores de produção fosse conhecida, era desconsiderada, sendo então aceita e utilizada a idéia da homogeneidade das áreas.

Goering (1992) e Goering \& Han (1993) relataram que, motivada por razões ambientais e econômicas, e viabilizada pelo desenvolvimento tecnológico, a agricultura de precisão tem sido cada vez mais utilizada. 0 gerenciamento da atividade produtiva agricola passa a ter, a partir deste momento, um novo enfoque. 
Diferentes termos e expressões têm sido utilizados para se caracterizar a utilização das técnicas de gerenciamento localizado das culturas. Os termos mais comuns encontrados na bibliografia são: a) Tecnologia de razões variáveis ("Variable Rate Technology - VRT"); b) Gerenciamento localizado de culturas ("Site-Specific Crop Management"); c) Cultivo auxiliado por computadores ("Computer Aided Farming") e d) Agricultura de precisão ("Precision Farming"), conforme relataram Kincheloe (1994) e Searcy, (1995), sendo esta última expressão a mais utilizada por inúmeros autores.

Evans et. al. (1994a) afirmaram que uma prática comum em áreas irrigadas com pivos-centrais é a utilização da chamada fertirrigação, caracterizada pela aplicação de fertilizantes juntamente com a água de irrigação. Tradicionalmente, são utilizadas dosagens homogêneas de fertilizantes e de água, aplicadas uniformemente sobre toda a área do pivocentral. Sendo as propriedades do solo e conseqüentemente as necessidades das plantas variáveis ao longo da área, as aplicações uniformes tanto de água quanto de fertilizantes nitrogenados acabam por causar problemas localizados, seja pela falta ou excesso de água e adubo. Um dos grandes problemas da super-dosagem destes produtos refere-se à lixiviação do excedente, o qual irá contaminar os lençóis freáticos.

Hummel et. al. (1996) afirmaram que as práticas gerenciais que caracterizam a chamada "agricultura convencional", tais como a consideração de uma fertilidade média do solo bem como a produtividade média da cultura tendem a assumir que toda uma área produtiva seja vista como sendo um campo homogêneo, quando na realidade, as propriedades e características do solo variam amplamente. Ainda segundo os autores, a agricultura de precisão pode contribuir consideravelmente para $\circ$ aumento da eficiência da produção agrícola por melhor adequar a utilização de insumos, principalmente de fertilizantes e defensivos químicos. 


\subsubsection{Conceitos básicos da agricultura de precisão.}

Conceitualmente, a agricultura de precisão confere um novo significado ao gerenciamento da produção agrícola, uma vez que está basicamente fundamentado na existência da variabilidade espacial dos fatores de produção. A área de produção passa a ser vista ou entendida como sendo uma coleção de pequenas sub-áreas, consideradas as menores unidades gerenciais, as quais são tratadas individualmente, a fim de que a rentabilidade econômica de cada uma delas seja maximizada. Ao seu oposto, a agricultura convencional baseia-se em aplicações profiláticas de defensivos e fertilizantes, conforme afirmaram Han et. al. (1994) e Searcy (1995).

As vantagens do gerenciamento localizado das culturas foram apresentadas por Goering (1992). Num exemplo ilustrativo, o autor considerou dois diferentes tipos de solo identificados pelas letras " $H^{n}$ e " $L$ ", cujos potenciais produtivos, decorrentes da clássica relação da resposta de produtividade da cultura em função do nível de fertilidade do solo, eram respectivamente elevado (Solo " $H$ ") e baixo (Solo " $L$ "). A aplicação de uma dosagem uniforme de fertilizantes, representada pela linha vertical " $f$ ", poderia elevar o nivel de fertilidade do solo " $L$ " para valores próximos ao limite de toxicidade, enquanto que para o solo " $\mathrm{H}$ ", a quantidade aplicada de nutrientes não permitiria se atingir o máximo potencial produtivo do solo. Conforme ilustra a Figura 1, com a utilização da agricultura de precisão, 0 agricultor poderia simplesmente deixar de aplicar no solo " $\mathrm{L}$ " uma determinada quantidade de fertilizantes, representada por $\Delta \mathrm{F}$, acarretando entretanto uma diminuição de produtividade, representada pelo intervalo $\Delta Y$ L. A quantidade "economizada" no solo "L" poderia então ser realocada, para o solo " $\mathrm{H}$ ", proporcionando desta forma um aumento de produtividade, representado por $\Delta Y_{H}$. Como a perda $\Delta Y_{L}$ de produtividade seria certamente menor que $\Delta Y_{H}$, a produtividade total, considerando-se os dois solos juntos, seria maior se comparada à situação inicial. 


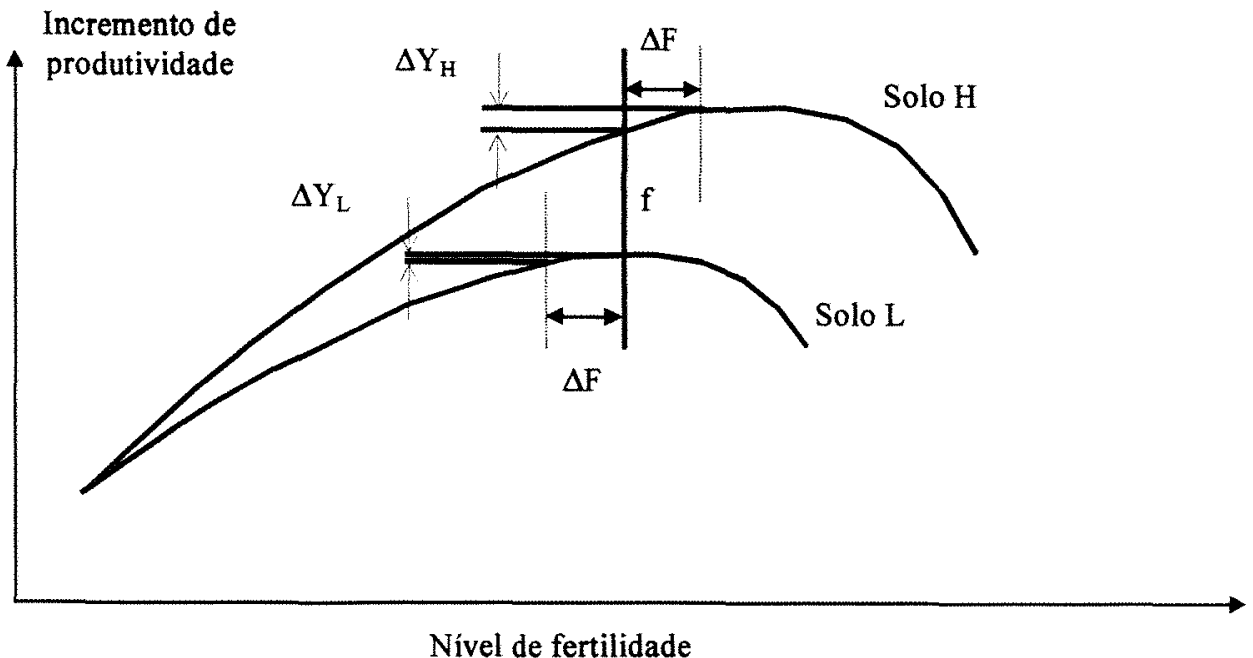

Figura 1. Produtividade da cultura em função do tipo de solo e do nivel de fertilidade considerado.

Fonte: Modificado de Goering (1992).

O fato mais importante a ser salientado é que o aumento da produtividade foi obtido apenas com a melhor alocação na aplicação dos fertilizantes, sem que houvesse aumento da quantidade utilizada. Ainda segundo Goering (1992), o objetivo maior da agricultura de precisão é aplicar localizadamente, e em razões variáveis para cada célula considerada, sementes, fertilizantes e demais insumos, a fim de se fazer o melhor uso do potencial do solo ao longo da área.

Um estudo que vem dar ênfase comprobatória aos conceitos apresentados por Goering (1992) foi realizado por Chancellor et. al. (1993 e 1994). A fim de se verificar o impacto e as vantagens da utilização das técnicas de gerenciamento e aplicação localizada de insumos, foram realizadas amostragens a intervalos eqüidistantes de 1 metro para a determinação da umidade, nitrogênio e infestação de plantas invasoras. Os resultados das análises de cada uma das amostras foram geoestatisticamente analisadas, através do software GEO-EAS, a fim de se determinar a variabilidade espacial de cada um dos 3 parâmetros considerados, respectivamente da umidade, concentração de nitrogênio e infestação de plantas invasoras. Um modelo de simulação foi então 
desenvolvido baseando-se em modelos matemáticos de incremento de produtividade e nos resultados geoestatísticos obtidos no ensaio, a fim de se comparar os incrementos de produtividade considerando-se métodos convencionais de irrigação e aplicação de fertilizantes e herbicidas, com os métodos de aplicação localizada. Os autores concluíram que a aplicação localizada de nitrogênio e de herbicida poderiam representar reduções $12 \%$ e $40 \%$ respectivamente na utilização de fertilizantes e herbicidas, em comparação com as aplicações homogêneas em área total. Os autores puderam concluir ainda que as vantagens da aplicação localizada diminuem a medida que o tamanho das sub-áreas consideradas aumentam.

Ao contrário do que parece, os conceitos do gerenciamento localizado das culturas, da subdivisão da área em células e da aplicação diferenciada de insumos não são novos. De acordo com Goering (1993), Stafford (1996a e 1996b), o surgimento de tais conceitos foi proposto pela primeira vez no ano de 1929 por C. M. Linsley e F. C. Bauer, pesquisadores da Estação Experimental Agrícola da Universidade de Illinois. Linsley e Bauer, estudando a acidez dos solos, notaram que esta variava amplamente, mesmo em pequenas áreas. Os pesquisadores destacaram então a importância da execução de estudos sistemáticos e detalhados a fim de se verificar, ponto a ponto, as reais necessidades de calcário para a correção de tal acidez.

Como no ano de 1929 não havia tecnologia capaz de aplicar automaticamente os conceitos desenvolvidos por Linsley e Bauer, os pesquisadores realizavam a amostragem do solo e a aplicação de insumos manualmente, viável para as pequenas áreas cultivadas na época. Conforme relatou Goering (1992), Linsley e Bauer citaram um agricultor que, na época, conseguiu com a adoção das técnicas de aplicação localizada e diferenciada, uma economia de $50 \%$ nos insumos utilizados, sem perda de produção. Com o aumento das áreas cultivadas, e com a introdução dos primeiros tratores motorizados, as técnicas foram abandonadas, uma vez que a tecnologia incorporada à estas primeiras máquinas inviabilizavam a utilização das técnicas de aplicação localizada. 
Goering (1993) afirmou que, embora Linsley e Bauer tenham realizado estudos apenas para a acidez do solo e a necessidade de calcário para sua correção, os conceitos utilizados pelos pesquisadores poderiam ser estendidos a todos os demais insumos tais como fertilizantes, defensivos e sementes, entre outros.

Devido aos avanços tecnológicos e científicos ocorridos, o conceito inicial da agricultura de precisão, proposto em 1929 por Linsley e Bauer sofreu alterações e aprimoramentos. Atualmente, a agricultura de precisão pode ser vista como um sistema integrado totalmente dependente de sistemas eletrônicos, mecânicos e computacionais, destinados ao levantamento em campo, e em condições dinâmicas, de um número bastante elevado de dados. Conforme afirmou Searcy (1995), o uso extensivo deste grande número de dados exige a utilização de sistemas de aquisição e análise dos dados, sistemas computacionais de processamento e suporte a decisão e equipamentos automáticos destinados a realização de operações em campo. A utilização de um sistema de navegação, capaz de fornecer o posicionamento geográfico de pessoas e equipamentos no campo, é também indispensável para o sucesso da agricultura de precisão.

\subsubsection{Exigências para a implantação da agricultura de precisão.}

De acordo com Yule et. al. (1996), a agricultura de precisão pode ser utilizada a fim de se realizar o uso de forma mais racional e econômica dos insumos, reduzindo-se assim os impactos ambientais, bem como as quantidades de produtos atualmente utilizados. Para tanto, é necessário se identificar localizadamente as reais necessidades da cultura. Os sistemas de informações geográficas ("G/S - Geographical Information Systems") que segundo os autores, são sistemas computacionais cujas características permitem o armazenamento, gerenciamento, análise e visualização de 
informaçōes geograficamente referenciadas, podem auxiliar os agricultores na identificação das células cujas capacidades produtivas sejam similares.

Yule et. al. (1996) afirmaram ainda que para a execução da agricultura de precisão, devem ser traçados alguns objetivos básicos essenciais, destacando-se: a) Identificar áreas homogêneas no interior da área produtiva com base nas características do solo; b) identificar variabilidade sazonal das culturas, causadas por influências transientes tais como estabelecimento das plantas, pragas, doenças e infestações de plantas invasoras e c) Desenvolver programas de gerenciamento localizado a fim se otimizar a utilização dos insumos, com base na predição do potencial produtivo da cultura. Os autores consideram como cruciais para 0 sucesso da agricultura de precisão, a elaboração dos mapas de produtividade da cultura, de mapas de solos e a identificaçăo de outros fatores que possam influenciar a produção, tais como pragas, doenças, umidade do solo, etc.

\subsubsection{Subdivisão da área em "células".}

Para a agricultura de precisão, a área produtiva é vista como sendo um conjunto de células, as quais passam a ser conceitualmente as menores unidades gerenciais do processo produtivo. Conforme afirmaram Han et. al. (1994), estas células devem ser consideradas como regióes uniformes cujas caracteristicas e propriedades do solo sejam aceitavelmente homogêneas. Assim, os autores evidenciam a importância da utilização de metodologias adequadas que permitam se determinar com segurança, as dimensões destas células, a fim de que suas características e propriedades possam ser consideradas uniformes. Deste modo, as dosagens de insumos recomendadas para as células podem ser também uniformes.

Han et. al. (1994) afirmaram ainda que a escolha das dimensões das células é um dos passos de maior importância para a agricultura de 
precisão. Os autores afirmaram que quanto menores forem as dimensões destas unidades gerenciais, tanto mais homogênea serão suas características e propriedades. Entretanto, existe um limite mínimo de tamanho, imposto pelas características físicas dos equipamentos, sensores e atuadores que realizam as operações localizadas.

Recentemente, vários pesquisadores têm utilizado a geoestatística como instrumento para a determinação das dimensões ideais das células, uma vez que esta ferramenta de análise pode determinar e quantificar a influência da distância entre os pontos e seus valores.

\subsubsection{Sistemas de posicionamento.}

De acordo com Stafford \& Ambler (1994), a execução de operações de campo espacialmente variáveis, como por exemplo, operações de aplicação localizada e diferenciada de insumos, mapeamento da produtividade, entre outras, somente podem ser realizadas com sucesso se contarem com um sistema adequado de posicionamento. Os autores afirmam ainda que a posição de um determinado ponto pode ser calculada a partir das distâncias e ângulos existentes entre este ponto e outros dois ou mais pontos cujas coordenadas sejam conhecidas. Os primeiros sistemas de localização utilizados na agricultura de precisão eram sistemas terrestres.

Como exemplo da utilização de sistemas terrestres de posicionamento, pode-se citar o trabalho desenvolvido por Searcy et. al. (1990), os quais utilizaram, para o posicionamento da colhedora em campo, um sistema terrestre composto por um receptor de microondas, instalado na colhedora, e mais dois emissores colocados nas bordas da área a ser mapeada. Segundo os autores, o sistema utilizado apresentou um erro aproximado de 2 metros no cálculo das coordenadas.

Nos sistemas terrestres, dois ou mais pontos fixos e de coordenadas conhecidas são marcados no campo. Um equipamento instalado na 
colhedora mede as distâncias e os ângulos entre ele e os demais pontos fixos e, a partir destes dados, calcula sua posição. Dentre os sistemas terrestres desenvolvidos, destacaram-se segundo Stafford \& Ambler (1994), os sistemas que utilizam ondas de rádio em freqüência de VHF $(160 \mathrm{MHz})$ e os sistemas cujo princípio de funcionamento baseiam-se na emissão de radiação visível (principalmente o "laser"). Ainda segundo os autores, alguns sistemas à laser desenvolvidos podem calcular a coordenada de um ponto móvel com uma acurácia de até 10 milímetros. Entretanto, esta incrível acurácia somente pode ser conseguida se o ponto móvel estiver a uma distância, em relação aos pontos fixos, não maior que 100 metros, exigência esta que inviabiliza a utilização destes sistemas para a agricultura de precisão. Uma das grandes desvantagens dos sistemas terrestres, apontadas por muitos autores como o fator que inviabilizou seu uso em escala comercial, refere-se à necessidade do constante deslocamento dos pontos fixos, devido ao baixo alcance dos equipamentos utilizados.

De acordo com Krüger et. al. (1994), dois distintos e independentes sistemas de navegação via satélite estavam em desenvolvimento no ano de 1994, ambos com previsão de entrarem em plena capacidade de operação num futuro próximo. Um destes sistemas, denominado "GLONASS", estava sendo desenvolvido pelos países formadores da antiga União Soviética. $O$ outro sistema, muito mais difundido, denominava-se "NAVSTAR Global Positioning System", mais conhecido como GPS, desenvolvido pelos Estados Unidos. Os autores relataram com detalhes o princípio de funcionamento de cada um dos sistemas, fazendo uma breve comparação entre eles, e concluíram que ambos os sistemas possuiam excelentes capacidades de determinação de posições com boa acurácia, em tempo real, sob quaisquer condiçōes climatológicas, sem interrupções e para um número ilimitado de usuários.

Goering \& Han (1993), afirmaram que um dos problemas para a execução das atividades relacionadas com a agricultura de precisão referiam-se exatamente às limitações dos sistemas terrestres de navegação. Os autores afirmaram que um sistema de navegação via satélite 
denominado "Sistema de Posicionamento Global - GPS" ("Global Positioning System"), representava a mais promissora solução para o problema da navegação.

Conforme relataram Krüger et. al. (1994), Stafford \& Ambler (1994) e Han et. al. (1995), o sistema GPS será formado, em sua versão final, por uma constelação de 24 satélites, dos quais 21 ativos e 3 de reserva, sendo que satélite possuirá uma órbita própria e conhecida, e emitirá uma composição de sinais que poderão ser captados, em terra, por receptores especiais de microondas, denominados receptores de GPS. Através do processamento dos sinais captados, o receptor poderá calcular sua posição. Entretanto, por motivos de segurança, os satélites poderão enviar propositadamente um sinal de interferência introduzindo um erro entre 30 e 100 metros na posição calculada pelo receptor.

Han et. al. (1995) afirmaram que para se aumentar a acurácia do sistema, poderia ser utilizada uma técnica de correção das posições, denominada correção diferencial. Assim, para o funcionamento do sistema de GPS diferencial ("Diferential Global Positioning System - DGPS"), um segundo receptor, denominado receptor ou estação base, deveria ser instalado em um ponto fixo e de coordenadas conhecidas. $O$ erro inserido propositadamente no sistema pode ser estimado através da comparação entre os valores calculados pelo receptor fixo de GPS e as coordenadas conhecidas do ponto. Assim, os valores dos erros podem ser transmitidos via rádio para o receptor móvel o qual fará a leitura do valor do erro enviado pela base através da utilização de um rádio receptor. $O$ valor da posição a ser armazenada poderia ser então previamente corrigida, descontando-se o valor do erro existente. Ainda segundo os autores, a correção diferencial de posições poderia também ser realizada em pós-processamento.

As principais fontes de erro dos sistemas de GPS e DGPS foram apresentadas por Stafford (1996a), conforme ilustra a Tabela 1, cuja análise indica que os erros de posicionamento dos receptores terrestres são influenciados concomitantemente pelos erros ocasionados por cada uma das diferentes fontes. Pode-se notar também que a correção diferencial de 
Tabela 1. Influência das principais fontes de erros associadas aos sistemas de posicionamento global com (DGPS) e sem (GPS) correção diferencial.

\begin{tabular}{l|c|c}
\hline \multirow{2}{*}{ Fonte do erro } & \multicolumn{2}{c}{ Magnitude do erro (metros) } \\
\cline { 2 - 3 } & GPS & DGPS \\
\hline Relógio do satélite & 15 & 0.1 \\
\hline Efeméride & 40 & 1.0 \\
\hline Orbita & 5 & 0.1 \\
\hline lonosfera & 12 & 1.0 \\
\hline Troposfera & 3 & 0.5 \\
\hline Multicaminhamento & 2 & 2.8 \\
\hline Ruído do receptor & 0.5 & 0.7 \\
\hline Erro estatístico total & 44.8 & 3.3 \\
\hline
\end{tabular}

Modificado de Stafford (1996a)

posicionamento pode ser eficaz para a minimização de quase todas as fontes de erro, com exceção do multicaminhamento. Neste caso, a correção diferencial não só foi ineficiente como acarretou aumento do erro.

Com relação às operaçōes de aplicação localizada de insumos e de mapeamento da produtividade, Stafford (1996a) afirmou que estas somente puderam ser implementadas a partir dos recentes avanços tecnológicos, os quais contribuiram para 0 aumento da precisão e acurácia dos equipamentos envolvidos, principalmente dos sensores e atuadores. A acurácia dos sistemas de posicionamento, notoriamente a do sistema GPS Sistema de Posicionamento Global - foi também indispensável para a viabilização da agricultura de precisão. $O$ principal desafio agronômico da implantação da agricultura de precisão é, segundo o autor, a determinação do nível de detalhamento a ser utilizado no levantamento de dados e na aplicação diferenciada de insumos. $O$ autor citou, por exemplo, que com a utilização de alguns tipos de sensores, foi possível se verificar, com grande acurácia, a variabilidade espacial da quantidade de nitrogênio mineral presente no solo, em leituras realizadas em distâncias de apenas alguns centímetros. $O$ autor questiona, entretanto, se existe realmente a necessidade de se realizar levantamentos de dados a intervalos táo pequenos. 
Ainda segundo Stafford (1996a), o sucesso da implantação de um programa de agricultura de precisão está diretamente ligado ao sucesso na implantação e condução de operações de sensoriamento e monitoramento, uma vez que a agricultura de precisão está fortemente apoiada na disponibilidade de quantidade significativa de dados e informaçōes relacionadas com as características do solo, da cultura e do clima, as quais devem ser apresentadas em formas gráficas através de mapas georeferenciados. Como a quantidade de dados a serem levantados é consideravelmente grande, seria pratica e economicamente inviável a aquisição manual. Somente com técnicas de aquisição automática, de baixo custo e elevada eficiência e velocidade, é viável a implantação da agricultura de precisão.

Com relação aos sistemas de posicionamento, a acurácia necessária deverá ser determinada pelo tipo de operação a ser realizada, conforme ilustra a Tabela 2. Ao contrário de Han et. al. (1994), Stafford (1996a) afirmou que para a determinação da acurácia necessária para cada operação, levou em consideração apenas as caracteristicas agronômicas e o tipo de operação a ser realizada. Assim, as dimensões das células criadas pela agricultura de precisão devem ser determinadas a partir dos conhecimentos agronômicos, principalmente no que se refere às dimensões superiores, uma vez que para a grande maioria das vezes, os tamanhos

Tabela 2. Necessidades de acurácia do sistema de posicionamento em funçăo de diferentes operaçőes em campo.

\begin{tabular}{l|c}
\hline \multicolumn{1}{c|}{ Operação } & $\begin{array}{c}\text { Acurácia necessária } \\
\text { (metros) }\end{array}$ \\
\hline Mapeamento da produtividade: & 10,0 \\
Aplicação diferenciada de defensivos & 1,0 \\
Em área total: & 0,10 \\
Entre linhas: & 0,10 \\
Semeadura em linhas: & 0,05 \\
Estrutura da cama de semeadura: & \\
\hline
\end{tabular}

Fonte: Stafford (1996a) 
mínimos são "impostos" pelas características dos sensores e equipamentos utilizados para a medição. Para determinados fatores, a diminuição exagerada do tamanho das células não implicaria necessariamente no aumento da qualidade da informação. $O$ autor afirmou ainda que a utilização de áreas menores que 15 ou 20 metros, para o estudo da variabilidade da produtividade de uma cultura, não apresentariam grandes vantagens.

Desta forma, Stafford (1996a) afirmou que diferentes operações ou atividades exigem diferentes acurácias dos sistemas de GPS. Para o mapeamento da produtividade, por exemplo, não há a necessidade de se utilizar sistemas de posicionamento com acurácia superior a 10 metros. Já para a aplicação localizada de defensivos entre as linhas de plantio, a acurácia do sistema de posicionamento devem ser maiores ou iguais a 10 centímetros $(0,10$ metros). $O$ autor salientou ainda que quanto maior a acurácia e precisão dos equipamentos destinados à realização das operaçōes localizadas, tanto maior o custo desta operação.

Gilbert (1997), referindo-se aos equipamentos de GPS, afirmou que a existência de erros nas atividades de aquisição de dados são normais. Geralmente, sem a realização da correção diferencial de posição, os equipamentos de GPS conseguem uma acurácia não maior que 100 metros, devido a existência de uma série de erros, provenientes de diferentes fontes. A utilização da correção diferencial, tanto em tempo real como em pósprocessamento pode, segundo o autor, minimizar a maioria desses erros.

Com relação aos tipos de erros a que os sistemas de GPS podem estar sujeitos, Gilbert (1997) destacou 6 tipos, considerados de maior importância, conforme ilustra a Tabela 3 . Ainda segundo o autor, o Departamento de Defesa dos EUA pode utilizar para a disponibilidade seletiva ("S/A - Selective Availability") tanto os erros "S/A Dither" como os "S/A Epsilon". Neste contexto, a correção diferencial de posição é eficaz para remover os erros devidos ao "S/A Dither", porém pode não ser eficaz na correção dos erros introduzidos ao "S/A Epsilon". 
Tabela 3. Principais fontes de erros associadas ao sistema GPS de posicionamento.

\begin{tabular}{|c|c|}
\hline Tipo de Erro & Descrição \\
\hline $\begin{array}{l}\text { Erros dos parâmetros } \\
\text { orbitais }\end{array}$ & $\begin{array}{l}\text { Os parâmetros orbitais dos satélites podem apresentar } \\
\text { erros, os quais afetam o cômputo da localização do mesmo, } \\
\text { resultando em pequenos erros de posição quando o satélite em } \\
\text { questão é utilizado pelo receptor. }\end{array}$ \\
\hline $\begin{array}{l}\text { Erros de propagação } \\
\text { dos sinais }\end{array}$ & $\begin{array}{l}\text { São erros causados pelas diferenças regionais na } \\
\text { ionosfera e troposfera, os quais alteram o tempo de percurso do } \\
\text { sinal GPS do satélite até o receptor. Este atraso no tempo } \\
\text { contribui para o aumento do erro do cálculo da posiçăo do } \\
\text { receptor. }\end{array}$ \\
\hline $\begin{array}{l}\text { Erros do relógio do } \\
\text { satélite }\end{array}$ & $\begin{array}{l}\text { Pequenos erros no relógio do satélite resultam em } \\
\text { pequenos erros de posiçăo. }\end{array}$ \\
\hline "S/A Dither" & $\begin{array}{l}\text { São causados pela degradação intencional do relógio do } \\
\text { satélite. }\end{array}$ \\
\hline "S/A Epsilon" & $\begin{array}{l}\text { São causados pela degradaçăo intencional dos } \\
\text { parâmetros orbitais dos satélites, causando erros significantes no } \\
\text { cálculo das posiçóes pelos receptores de GPS. Săo erros } \\
\text { semelhantes aos erros nos parâmetros orbitais, porém de } \\
\text { magnitude muito maior. }\end{array}$ \\
\hline Multicaminhamento & $\begin{array}{l}\text { São causados pela reflexăo do sinal emitido pelos } \\
\text { satélites sobre superficies refletoras. A reflexão destes sinais faz } \\
\text { com que o receptor de GPS receba múltiplas cópias do mesmo } \\
\text { sinal, aumentando assim os erros no cálculo da posiçăo. }\end{array}$ \\
\hline
\end{tabular}

Fonte: Modificado de Gilbert (1997).

\subsubsection{Sensores.}

De acordo com Hummel et. al. (1996), a agricultura de precisão exige a utilização de vários tipos de sensores e equipamentos destinados ao levantamento localizado de dados relacionados aos fatores que afetam 0 desenvolvimento e produtividade das culturas, tais como condições nutricionais, infestações de plantas invasoras, umidade do solo, topografía da área, matéria orgânica, salinidade e fertilidade do solo e profundidade de 
camadas de compactação. Ainda segundo os autores, o monitoramento das propriedades físico-químicas que afetam o crescimento das plantas é uma tarefa básica na agricultura de precisão, e concluíram que a utilização de sensores eletrônicos capazes de medir em tempo real determinados parâmetros, tais como umidade do solo, presença de plantas invasoras, entre outros, serão cada vez mais indispensáveis.

\subsubsection{Sistemas de informações geográficas - SIG}

Uma outra ferramenta de extrema importância para a agricultura de precisão refere-se aos chamados sistemas de informações geográficas SIG, também conhecidos como GIS ("Geographical Information Systems").

Pedersen, (1994) destacou a importância dos sistemas de informaçōes geográficas para a agricultura de precisão. Segundo o autor, estes sistemas são essenciais para a manipulação georreferenciada de dados e para a apresentação gráfica, pelo fato de permitirem que diferentes parâmetros com as mesmas informações geográficas sejam armazenados, visualizados e manipulados em diferentes "camadas".

Em conformidade com Pedersen (1994), Evans et. al. (1994b) afirmaram que pelo fato da agricultura de precisão estar fundamentalmente baseada e envolvida com elevada quantidade de dados geograficamente referenciados, os sistemas de informações geográficas - SIGs tornaram-se ferramentas essenciais.

De acordo com Evans et. al. (1994b e 1995), os sistemas de informações geográficas podem ser considerados como ferramentas poderosas de manipulação de dados georreferenciados, porém sua utilização não deve ser exagerada para a agricultura de precisão, uma vez que tais sistemas apresentam algumas limitações. As principais limitações dos sistemas de informação geográfica para aplicações na agricultura de precisão referem-se, segundo os autores, aos limitados recursos das 
ferramentas de análise incorporadas nestes softwares, principalmente no que se refere às técnicas e rotinas de interpolação espacial de dados. De todos os métodos de interpolação testados pelos autores os métodos de distância proporcional convencional e distância proporcional não paramétrico mostraram-se melhores que os vários métodos de "krigagem". Outro problema relativamente sério destes programas estão relacionados com a inexistência de relações entre estes softwares e outros programas especialistas para a agricultura de precisão, tais como os sistemas de simulação de culturas.

Evans et. al. (1994b e 1995) afirmaram ainda que o ponto crucial do sucesso da utilização dos sistemas de informações geográficas está estreitamente ligado à criação da base de dados a ser analisada, a qual compõe-se de dados relativos às características do solo, tais como textura, nutrientes ( $N, P, K$, etc...) e das culturas, principalmente com referência à produtividade. Esta é segundo os autores, a etapa de maior importância e também a que exige o maior tempo de todo o projeto GIS.

\subsubsection{Etapas e operações que compõem a agricultura de precisão.}

Tomando-se como base 0 que foi discutido anteriormente, principalmente em relação aos conceitos da agricultura de precisão, pode-se concluir que ela não é uma atividade única, mas sim um conjunto de operações. De acordo com Stafford (1996b), a agricultura de precisão compõe-se de quatro subsistemas essenciais:

a) Sensoriamento ou monitoramento do solo e da cultura;

b) Sistema de posicionamento geográfico em campo;

c) Mapeamento de campo;

d) Sistemas automáticos e de precisão para aplicação de insumos com controle automático. 
A agricultura de precisão, segundo o autor, não é uma atividade ou operação estanque, mas sim um processo cíclico e contínuo, formado por três etapas básicas as quais os quatro sub-sistemas essenciais considerados, conforme ilustra a Figura 2. As três etapas básicas apresentadas por Stafford (1996a) são:

a) Aquisição e análise de dados;

b) Interpretação dos resultados;

c) Aplicação localizada de insumos.

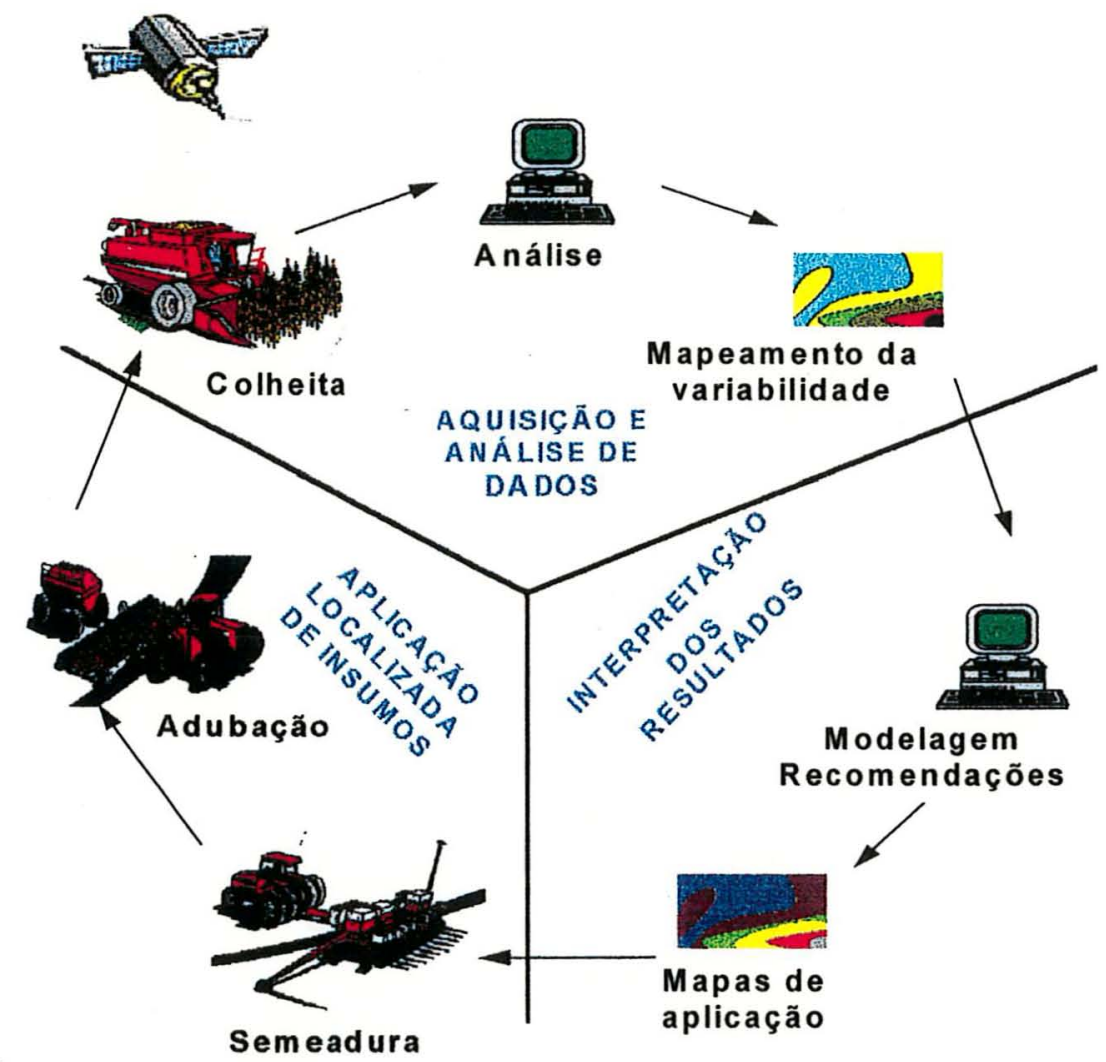

Figura 2. Ciclo da agricultura de precisão. A interação dos quatro subsistemas essenciais dispostos em três etapas básicas.

Modificado de Stafford (1996b)

Uma representação mais simples e objetiva da agricultura de precisão, que apresenta o fluxo de dados característico da técnica, foi apresentado por Stafford (1996a), conforme ilustra a Figura 3. Inicialmente, 
procede-se à coleta da dados em campo. Os dados coletados nesta etapa são então processados, analisados e interpretados com 0 auxílio de sistemas computacionais especialistas e com base nos conhecimentos agronômicos, de forma a auxiliar o processo gerencial de tomada de decisão. Finalmente, baseando-se nos resultados das análises e interpretações realizadas os processos de controle são elaborados.

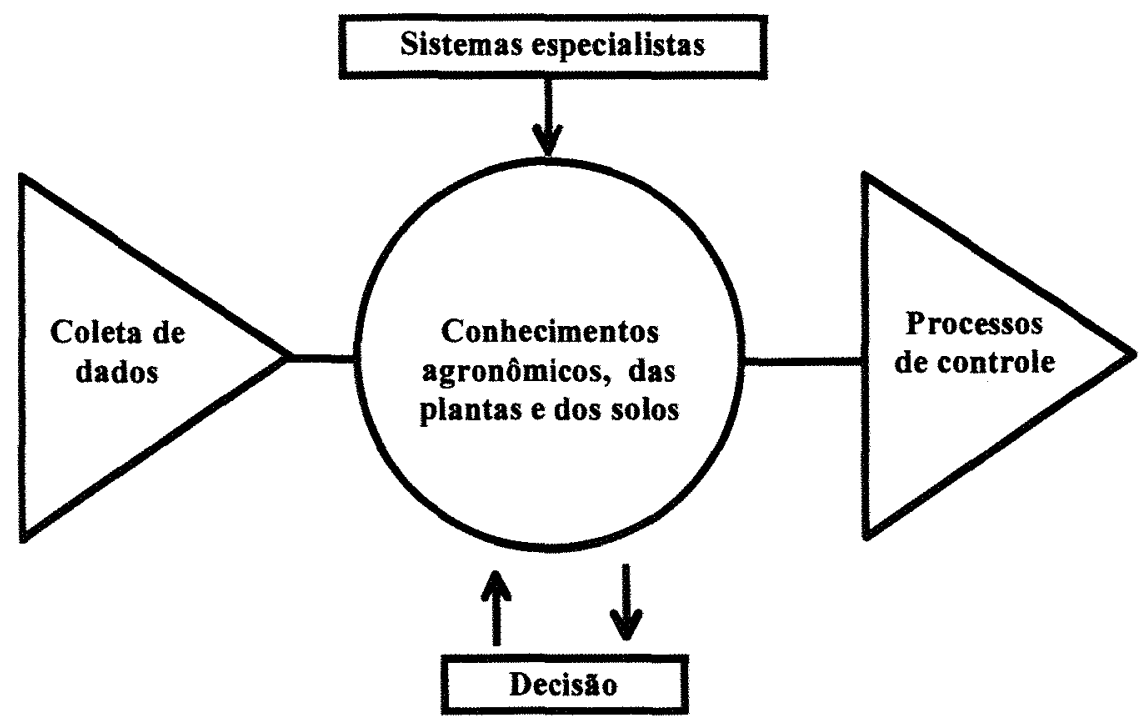

Figura 3. Representação gráfica do fluxo de dados característico da agricultura de precisăo.

Modificado de Stafford (1996a).

\subsubsection{Aquisição e análise de dados.}

O processo da agricultura de precisão tem início a partir do levantamento e análise de dados que possam determinar e caracterizar a área produtiva. Para tanto, é necessária a obtenção de um número suficiente de dados a respeito dos fatores de produção, tais como fertilidade do solo, 
produtividade da cultura, umidade dos grãos colhidos, entre outros. Assim, a aquisição de dados deve ser realizada localizadamente. A principal atividade desta primeira fase refere-se ao monitoramento ou mapeamento da produtividade da cultura colhida. A importância do mapeamento da produtividade é apresentada por Birrell et. al. (1996). De acordo com o autor, a implementação do gerenciamento localizado das culturas depende das variações da produtividade e do potencial produtivo dos campos e consideram, portanto, que os mapas de produtividade são importantes para a definição das estratégias de implementação e avaliação das técnicas da agricultura de precisão.

Além do mapeamento da produtividade é importante também que seja realizado um acompanhamento das condições do campo para as safras futuras. Neste contexto, uma das preocupações refere-se à presença de plantas invasoras na área. Assim como todos os demais fatores de produção, a existência de plantas invasoras também ocorre com variações ao longo da área. De acordo com Stafford et. al. (1996), o combate à estas plantas pode também ser realizado localizadamente, sob os conceitos da agricultura de precisão, uma vez que a aplicação com dosagem constante em área total representa desperdício de produto, aumento do custo de produção e maior impacto ambiental.

Para a aplicação localizada de herbicidas é necessário, entretanto, a elaboração de um mapa de identificação e localização das plantas daninhas. Stafford et. al. (1996) destacaram a importância da utilização de coletores de dados acoplados à um receptor de GPS, montados num sistema portátil que possa facilmente ser levado à campo a fim de se determinar a localização das plantas daninhas. Uma vez identificadas e localizadas as áreas de infestação, pode-se gerar um mapa de prescrição contendo as recomendações agronômicas de forma geo-referenciada. 


\subsubsection{Interpretação dos resultados.}

A segunda etapa da agricultura de precisão tem como finalidade a interpretação dos dados coletados, sendo que para tanto devem ser utilizados, segundo Stafford (1996b), sistemas computacionais de suporte à decisão e de modelagem matemática, capazes de gerar mapas de aplicação de insumos.

Uma importante ferramenta que pode ser utilizada para melhor compreender as causas da variabilidade espacial da produtividade de uma determinada cultura ou até mesmo para se planejar ações futuras, refere-se à utilização de modelos matemáticos. Um exemplo desta técnica foi apresentada por Bresler et. al. (1981). No trabalho, os autores tentaram determinar as relações existentes entre a produtividade de uma determinada cultura e os componentes da fase líquida do solo. Os autores concluíram que este tipo de ferramenta poderá ser utilizado para estimar e predizer a produtividade de uma cultura a partir de informações da distribuição da salinidade do solo da área produtiva, além de permitir a realização de análises econômicas mais detalhadas.

De acordo com Cahn et. al. (1994), a variabilidade espacial de determinadas propriedades do solo, bem como as das concentrações de nutrientes precisam ser determinadas a fim de que as práticas de recomendação e aplicação localizada e diferenciada de insumos possam ser desenvolvidas. Para o estudo, os autores utilizaram uma área experimental de aproximadamente 3,3ha para a realização de amostragens de solo a espaços de 50 metros. De uma sub-área de aproximadamente 0,25ha previamente selecionada foram retiradas aleatoriamente 200 amostras de solo, a partir das quais foram obtidas sub-amostras posteriormente analisadas para a determinação da concentração de nitrogênio, fósforo, potássio, matéria orgânica e umidade. Os autores concluíram que a concentração de nutrientes variava consideravelmente ao longo da área. Relataram ainda a grande importância da utilização da geoestatística como 
ferramenta poderosa tanto para o planejamento de estratégias de amostragens de solo como para a determinação das zonas de aplicação localizada. Concluíram também que os padrões ou modelos de amostragens devem ser flexíveis para permitirem a obtenção de uma melhor caracterização das propriedades do solo.

Um outro exemplo da utilização de programas de simulação que auxiliam o processo de gerenciamento da atividade produtiva foi relatado por Evans et. al. (1994a). De acordo com os autores, a união de modelos de simulação de culturas e de sistemas de informações geográficas permitiram se analisar a distribuição dos potenciais de lixiviação de nitrogênio em áreas irrigadas com pivos-centrais. A utilização destes sistemas permite, segundo os autores, a visualização e estudo de diferentes cenários ou situações de gerenciamento.

\subsubsection{Aplicação localizada de insumos.}

O ciclo é completado com a terceira etapa, caracterizada exatamente pela aplicação localizada e em taxas variáveis dos insumos, baseando-se nos mapas de aplicação gerados a partir das recomendações agronômicas realizadas.

De acordo com Paice et. al. (1996), as práticas agronômicas atuais visam determinar uma densidade média de infestação de plantas daninhas para toda a área produzida para que, sobre estes valores médios, sejam realizadas as prescrições de dosagem e tipo do defensivo químico a ser aplicado. Os autores afirmaram que as vantagens econômicas e ambientais da aplicaçăo localizada e diferenciada destes produtos têm sido fortemente evidenciadas. Para a aplicação localizada de herbicidas é necessário se localizar de forma geo-referenciada, as ocorrências de infestaçōes de plantas invasoras ao longo da área e quantificar a densidade de cada uma destas infestações. Com base na localização e densidade das infestações, 
os mapas de prescrição devem ser elaborados. A dose a ser aplicada e a mistura dos herbicidas a serem aplicados devem ser considerados, a fím de se obter um nível ótimo de controle. Deve-se ainda adicionar uma área de bordadura para eliminar eventuais erros tanto de aplicação localizada quanto no levantamento e localização das infestações.

Paice et. al. (1996) consideraram ainda como elementos chaves para o sucesso das operações de aplicação localizada de herbicidas, a existência de equipamentos que garantam a acurácia da dose de produto aplicado, afirmando que para a agricultura de precisão, tal acurácia é comparativamente muito mais importante do que a manutenção da dosagem constante para a agricultura convencional. Outras características importantes destacadas pelos autores referem-se ao intervalo de dosagens que os equipamentos devem poder aplicar, ao tempo de resposta destes equipamentos, e a aplicação concomitante de diferentes produtos.

Mohamed et. al. (1996) afirmaram que a aplicação localizada de insumos pode trazer beneficios agronômicos e econômicos, caso sejam utilizadas técnicas cuidadosas de mapeamento do solo. A eficácia na aplicação localizada de fertilizantes somente poderá ser obtida partindo-se de uma boa compreensão das relações existentes entre a intensidade de amostragem do solo, dos custos associados à esta tarefa e dos benefícios decorrentes da operação. De acordo com os autores, o método de amostragem de solo, o número de amostras retiradas e também o método de interpolação utilizados para a geração dos mapas de fertilidade do solo devem conferir boa representatividade. No estudo realizado por Mohamed et. al. (1996), foram retiradas amostras de solo obedecendo-se 3 diferentes densidades, em 3 grades de diferentes dimensões $(20 \times 40 \mathrm{~m}, 40 \times 40 \mathrm{~m}$ e $60 \times 40 \mathrm{~m}$ respectivamente), totalizando-se 244 amostras. Para se estudar os efeitos da interpolação dos resultados na geração dos mapas, os autores realizaram 6 diferentes metodologias de interpolação, destacando-se: a) BiLinear; b) Polinomial; c) "Fault" (uma variação da bi-linear); d) Curvatura mínima, e) Cúbica; f) Krigagem. Os autores concluíram que para 0 mapeamento da concentração de fósforo na área estudada, as amostragem 
de solo deveriam ser realizadas a distâncias entre 50 e 100 metros, totalizando respectivamente 4 e 1 amostras por hectare. Amostragens realizadas a distâncias inferiores a 50 metros (mais de 4 amostras por ha) não aumentariam significativamente a representatividade da área. Já amostras realizadas a distâncias superiores a 100 metros (menos de 1 amostra por ha) acarretariam perdas significativas de informações a respeito da variabilidade espacial do fator estudado. Sendo a amostragem de solos uma atividade financeiramente dispendiosa, deve-se levar em conta, portanto, a relação custo/benefício do mapeamento dos níveis de nutrientes no solo. O número de amostras não deve ser pequeno ao ponto de que informações importantes da variabilidade do nutriente estudado sejam perdidos, porém não deve ser exageradamente grande devido aos custos das análises do solo.

\subsection{Mapeamento da produtividade.}

O mapeamento da produtividade é considerado por diversos autores uma das etapa mais importantes da agricultura de precisão. Assim, a qualidade de todo 0 processo de gerenciamento localizado depende diretamente da qualidade e fidelidade das informaçōes contidas nestes mapas. Desta forma, é indispensável que sejam realizadas algumas considerações a respeito desta atividade.

\subsubsection{Tecnologia necessária para o mapeamento da produtividade.}

Wagner \& Schrock (1989) consideraram como sendo elementos chaves para a obtenção dos mapas de produtividade os sensores de fluxo de grãos, os sistemas de posicionamento e os sistemas de aquisição de dados. Assim, os sensores de fluxo de grãos, constituintes do sistema de 
medição, possuem como objetivo principal medir "em tempo real", instantânea e concomitantemente com a colheita, a quantidade de grãos produzida pela cultura numa determinada unidade de área. O sistema de aquisição de dados é responsável por armazenar os dados de produção, obtidos pelo sistema de medição da colheita, juntamente com as informações de posição, fornecidas pelo sistema de posicionamento.

De acordo com Han et. al. (1995), os mapas de produtividade são um importante componente da agricultura de precisão, pois identificam e quantificam a variabilidade espacial da produtividade das culturas, podendo ser utilizados para identificar problemas localizados, além de auxiliar os processos de gerenciamento localizado. Ainda segundo os autores, a tecnologia de mapeamento da produtividade está baseada no monitoramento da produtividade em tempo real e no posicionamento da colhedora no campo, durante a colheita. Para tanto, vários tipos de sensores foram desenvolvidos.

A produtividade de uma determinada cultura, conforme argumentaram Stafford et. al. (1996a), é influenciada por uma série de efeitos combinados e por uma vasta quantidade de fatores do solo e da própria cultura, os quais apresentam-se espacialmente diferenciados, sendo que os mapas de produtividade apenas permitem se visualizar as variações desta ao longo da área, sem, no entanto, indicar suas causas.

Reitz \& Kutzbach (1994 e 1996), em concordância com os autores anteriormente citados, afirmaram que os mapas de produtividade, além de úteis para a identificação de problemas localizados, poderiam ser utilizados para localizar e até quantificar a absorção de nutrientes por parte das plantas. Os mapas de produtividades, elaborados em anos consecutivos, poderiam ser comparados entre si, como forma de se avaliar os resultados obtidos com o processo de gerenciamento utilizado. Para a realização do mapeamento da produtividade de uma determinada cultura são exigidos um sistema de medição de produtividade e um sistema de localização.

Baerdemaeker et. al. (1985), numa breve revisão referente aos tipos de sensores utilizados para medição da quantidade de grãos, mencionaram 
a existência de apenas dois principios básicos de funcionamento, dentro dos quais vários tipos de sensores podem ser classificados. 0 primeiro princípio refere-se à medição de um fluxo de massa através de métodos volumétricos, e o segundo na medição do fluxo de massa por meio de métodos não volumétricos. Dentre os métodos volumétricos, confirmaram a existência de sistemas mecânicos descontínuos, sistemas mecânicos contínuos e sistemas ópticos. Em relação aos sistemas baseados na medição do fluxo de massa não volumétricos, destacaram a existência de sensores medidores de impacto e de torque, sensores de raios-gama e raios- $x$, sensores capacitivos, ópticos, e até de microondas com efeito Doppler.

\subsubsection{Equipamentos e metodologias utilizadas}

Um dos primeiros sistemas de medição de massa de grãos foi desenvolvido por Sabir et. al. (1976). O sistema baseava-se na medição da velocidade do fluxo da massa de grãos que atravessava um tubo de dimensões conhecidas. A medição desta velocidade, bem como da densidade média da massa de grãos era realizado com um radar microondas com efeito Doppler. As principais vantagens da utilização deste sistema, segundo os autores, referiam-se ao fato do sensor utilizado para a medição não interferir no fluxo da massa de grãos, não causando desta forma a alteração de sua velocidade, por oferecer resistência ao fluxo. Testes de laboratório indicaram que o sistema possuía uma elevada acurácia, tempo de resposta muito alto e era linear para os valores de fluxo de massa estudados. A utilização do sistema em condições dinâmicas de trabalho, como por exemplo em colhedoras combinadas não foi apresentada ou discutida, sendo que apenas aplicações industriais foram recomendadas.

Baerdemaeker et. al. (1985) desenvolveram um sistema de medição de fluxo de massa. O sistema era composto por um cilindro semicircular de dimensões conhecidas pelo interior do qual a massa de grãos era 
conduzida, promovendo o surgimento de um momento de torção, o qual era medido por uma célula de carga. A força medida pelo sensor, sendo proporcional ao fluxo de grãos que passava pelo interior do tubo, é utilizada para se estimar a produtividade da cultura. Os autores citam, entretanto, que a utilização do sistema em condições reais de campo seria bastante difícil. Tal dificuldade dar-se-ia principalmente pela grande sensibilidade do sistema às variações ocorridas em condições de campo, variações ocasionadas pela densidade e umidade dos grãos, inclinação da área e às vibrações a que o sistema estaria sujeito, mesmo considerando que os experimentos em laboratório tenham mostrado valores coerentes e satisfatórios.

Searcy et. al. (1989) desenvolveram um sistema de medição mecânico do tipo volumétrico, composto por um rotor com aletas, instalado logo abaixo da extremidade de descarga do cilindro condutor de grãos, no interior do tanque graneleiro de uma colhedora. O sistema recebia e acumulava os grãos colhidos, até que o volume sobre este atingisse um valor próximo a 4,39 litros, identificado por um sensor capacitivo quando então um sistema eletro-eletrônico comandava um motor e uma válvula hidráulica, fazendo o rotor girar, descarregando assim a massa de grãos. A cada rotação do mecanismo dois pulsos elétricos eram gerados. O fluxo dos grãos é determinado em função do intervalo de tempo entre os pulsos e do volume máximo de grãos acumulado sobre o rotor. A fim de suavizar os dados coletados, eliminando-se os valores de pico, os autores evidenciaram a importância da realização de uma filtragem dos valores. Técnicas clássicas de filtragens digitais não puderam ser utilizadas segundo os autores, uma vez que a freqüência dos pulsos elétricos gerados pelo sistema não era constante. Foram então utilizados algoritmos baseados no cálculo de médias aritméticas para o tratamento dos dados, os quais possibilitaram a suavização dos valores de pico, sem que a redução da variabilidade original dos dados fosse grande. Os autores concluíram que o sistema de medição desenvolvido possibilitou a criação dos mapas de produtividade da cultura considerada, embora modificaçőes fossem necessárias para seu aprimoramento. Os mapas de produtividade foram elaborados considerando- 
se 3 niveis de produtividade para a área de menor variabilidade estudada e 5 níveis de produtividade para a área de maior variabilidade.

Um outro sistema de medição de fluxo de massa foi desenvolvido por Wagner \& Schrock (1989). No sistema, a massa de grãos colhida é direcionada para uma das extremidades do cilindro condutor, a qual é pivotada. Por meio de um transportador helicoidal, o produto colhido é transportado até a outra extremidade do cilindro, suspensa e conectada a uma célula de carga. A massa de grãos é descarregada no interior de um sub-tanque, suspenso por três outras células de carga. Um computador portátil é utilizado parar fazer a aquisição dos seguintes dados: a) Velocidade de rotação da rosca sem-fim do cilindro condutor; b) Peso da extremidade do cilindro condutor, indicado por uma célula de carga de $450 \mathrm{~N}$ de capacidade nominal; c) Aceleraçăo horizontal do cilindro condutor, fornecida por um acelerômetro situado na extremidade de descarga deste; d) Aceleração vertical da colhedora, fornecida por outro acelerômetro, situado na extremidade pivotada do cilindro condutor; e) A massa acumulada de grãos descarregados no sub-tanque graneleiro era medida por três células de carga de $26,4 \mathrm{kN}$ de capacidade nominal total. Como forma de minimizar os erros de leitura ocasionados pelas vibrações a que o sistema fica sujeito em condições dinâmicas de operação, os autores utilizaram uma filtragem eletrônica dos sinais fornecidos pelos sensores, através de um filtro tipo passa baixa, sendo este método considerado eficiente na eliminação dos ruídos. Ainda segundo os autores, o sistema foi capaz de medir, com um erro aproximado de $\pm 3,0 \%$, a produtividade da cultura estudada. Os autores concluíram que a filtragem eletrônica, através da utilização de filtros tipo "passa baixa" mostrou-se significantemente eficiente na redução dos "ruídos", caracterizados por sinais de interferência de alta frequência, cujas principais fontes provêm das vibrações ocasionadas pela rotação do cilindro condutor, do motor e outras peças rotativas na colhedora.

Auernhammer et. al. (1994) utilizaram duas colhedoras, instrumentadas com diferentes sistemas de medição de produtividade, em estudos realizados em diferentes áreas e culturas de grãos em dois anos 
consecutivos. Uma das colhedoras estava equipada com um sistema volumétrico de medição da produtividade, o qual utilizava um rotor com aletas como sensor. A segunda colhedora foi instrumentada com um sistema de medição de fluxo de massa, baseado na absorção de raios gama. Em ambas as colhedoras foram instalados sistemas GPS, com equipamentos da mesma marca e modelo. A aquisição dos dados de posição e de produtividade foram coletados e armazenados separadamente em dois computadores portáteis, referenciados à hora da aquisição. De acordo com os autores, os dois sistemas de medição da produtividade foram calibrados de acordo com as instruções fornecidas pelos fabricantes dos equipamentos, isto é, a cada início de operação e a cada mudança de campo. Ainda segundo os autores, para minimizar os erros de medição da produtividade, 0 sistema volumétrico de medição foi recalibrado após cada enchimento do tanque graneleiro da colhedora. A carga de cada um dos tanques graneleiros foi transportada separadamente e pesada. Simultaneamente, a umidade $e$ a densidade destes grãos eram determinadas através de amostragens aleatórias. Para o sistema volumétrico de medição, os autores afirmaram que houve importante aumento da acurácia na determinação da produtividade devido à recalibração do sistema a cada tanque colhido, uma vez que o volume de material é grandemente influenciado pela densidade e umidade dos grãos. As principais fontes de erro referentes ao sistema de medição de raios gama, segundo os autores estavam relacionados com a hora da colheita, os quais causaram alteraçōes na umidade, estrutura da superfície e outras alterações nos grãos, com a umidade dos grãos e ainda com o tipo dos grãos. Os autores concluíram ainda que o sistema volumétrico de medição somente obteve elevada acurácia enquanto a densidade dos grãos foi determinada durante a calibração e considerada no sistema. Assim, os autores consideraram essencial o desenvolvimento de um sistema automático de calibração para este equipamento, a fim de eliminar erros grosseiros que poderiam ser cometidos. A recalibração constante, por questões práticas, não seria viável. 
Reitz \& Kutzbach (1996) afirmaram que para a determinação da produtividade de uma determinada cultura, era necessário se medir a quantidade de grãos colhidos numa determinada área. A determinação da área poderia ser obtida através da multiplicação da largura efetiva de corte (obtida através de transdutores ultra-sônicos) pela velocidade de deslocamento da colhedora, medida com a utilização de um radar. Para a medição da quantidade de grãos colhidos, os autores utilizaram um sistema de medição de fluxo de massa de grãos constituído de um conjunto de sensores emissores e receptores de luz, instalados no interior de elevador de treliças da colhedora. O tempo de interrupção do sinal luminoso, proporcional à quantidade de grãos colhidos, era utilizado para se estimar a massa de grãos existentes sobre as treliças do elevador. Um sistema automático e não contínuo, destinado à determinação da densidade dos grãos e um equipamento de medição da umidade dos grãos foram também utilizados no trabalho. As vibrações a que a colhedora estava sujeita puderam ser compensadas através da utilização de 3 conjuntos de barreiras luminosas dispostas em diferentes posições no elevador de treliças. As variações das características dos grãos, tais como umidade e densidade também puderam ser consideradas durante 0 processo de medição da produtividade, através da utilização dos sistemas automáticos de medição da densidade e da umidade. Os autores concluíram que o erro na determinação da produtividade para o sistema utilizado foi próximo a $3 \%$, porém, quando a colhedora trabalhava em locais declivosos, este erro atingiu valores próximos a $10 \%$. Stafford et. al. (1996a) desenvolveram um sistema de medição de produtividade composto por sensores capacitivos, os quais foram instalados no final do tubo de descarga de grãos, no interior do tanque de uma colhedora. O princípio de funcionamento do sistema baseava-se na capacitância elétrica e na constante dielétrica da mistura ar + grãos que passa pelos sensores. O equipamento contava com dois sensores capacitivos, cada um trabalhando a uma determinada freqüência $(10 \mathrm{KHz}$ e 2Mhz). De acordo com os autores, o sistema de medição foi calibrado "in situ", através da descarga de $500 \mathrm{~kg}$ de grãos, despejados no início do 
cilindro condutor com fluxo constante, calculado a partir do tempo e peso total do material descarregado. Foram realizados mapeamentos de produtividades em campos de 6 ha. de área em quatro anos consecutivos.

\subsubsection{Fontes de erros existentes no mapeamento da produtividade.}

O mapeamento da produtividade das culturas é atualmente a base da agricultura de precisão, tendo forte influência sobre todo o processo do gerenciamento localizado. Assim, Blackmore et. al. (1996) afirmaram ser indispensável que as variações apresentadas nos mapas representem efetiva e confiavelmente as diferenças existentes no campo, e não sejam ocasionadas por erros sistemáticos. De acordo com os autores existem diversas fontes de erros associadas aos mapas de produtividade, destacamse o tempo de atraso no processamento dos grãos e a imprecisão da largura efetiva de corte da plataforma da colhedora.

Blackmore et. al. (1996) destacam ainda que os erros de posicionamento do sistema de GPS, as perdas na colheita e a acurácia e calibração dos sensores são outras importantes fontes de erros. 


\section{MATERIAL E MÉTODOS.}

Neste capitulo, são descritos os materiais utilizados e os métodos adotados para a condução do deste.

\subsection{Material.}

Os materiais citados no presente trabalho referem-se à área em que a cultura foi implantada e aos equipamentos e sistemas empregados. Inicialmente, caracterizou-se a área e a cultura utilizados neste estudo. São descritos, posteriormente, cada um dos equipamentos e sistemas utilizados, apresentando-se suas características técnicas e configurações adotadas.

\subsection{1. Área e Cultura.}

O monitoramento da colheita mecanizada foi realizado durante o período de 26 de junho a 01 de julho de 1997. A área colhida, conforme ilustra a Figura 4, possui aproximadamente 7 ha, subdivididos em 6 talhões separados por terraços de aproximadamente $2 \mathrm{~m}$ de base, a qual foi semeada entre os dias 16 a 20 de janeiro de 1997 com a variedade AL-25 de milho (Zea mays L.), cujas sementes foram produzidas pela fazenda Ataliba Leonel ("milho safrinha"). Nesta área, o milho foi semeado utilizando- 


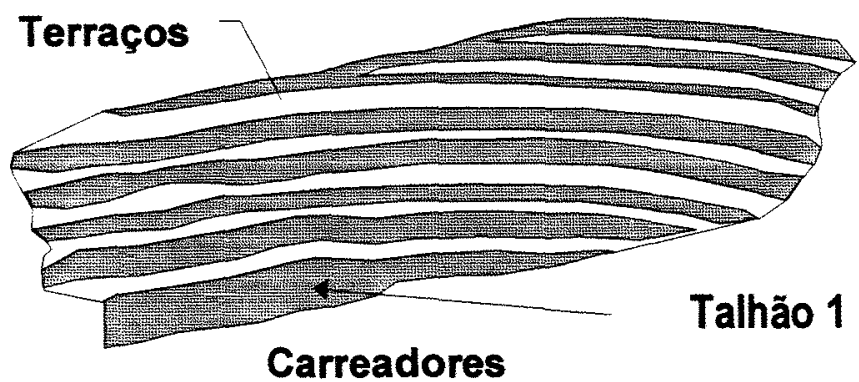

Figura 4 Representação esquemática (croqui) da área utilizada para o trabalho.

se um espaçamento entre linhas de $0,90 \mathrm{~m}$, e uma densidade populacional média de 55.000 plantas por ha, tendo sido conduzida de forma convencional.

\subsubsection{Colhedora.}

A colheita mecanizada da área experimental foi realizada com uma colhedora Massey Fergusson, modelo 6845, equipada com uma plataforma de milho para 4 linhas. Para a realização da colheita, a máquina foi previamente instrumentada com um sistema automático de medição da produtividade, constituído de um sub-tanque graneleiro apoiado exclusivamente sobre quatro células de carga cujas características serão apresentadas posteriormente. $O$ referido sistema, especialmente desenvolvido para este trabalho, será descrito no item 3.1.3. 


\subsubsection{Sistema automático de medição da produtividade.}

Os sistemas comerciais e/ou experimentais de medição da produtividade descritos anteriormente, baseavam-se na medição do fluxo de massa, os quais mediam a quantidade de grãos colhidos através de mecanismos volumétricos, como os descritos por Searcy et. al. (1989), Reitz \& Kutzback (1994), Auernhammer et. al. (1994), ou através de métodos não volumétricos, como os descritos por Sabir et. al. (1976), Baerdemaeker et. al. (1985), Wagner \& Schrock (1989), entre outros. Diferentemente destes, o sistema desenvolvido neste trabalho foi projetado e construído para medir diretamente, e em tempo real, o peso do material colhido, não exigindo para tanto que fosse determinada a umidade ou a densidade dos grãos, necessárias para os demais sistemas de medição descritos na bibliografia.

Para tanto, um sub-tanque graneleiro de formato trapezoidal, conforme ilustrada a Figura 5 , foi construído com cantoneiras de $50,8 \mathrm{~mm} \times$

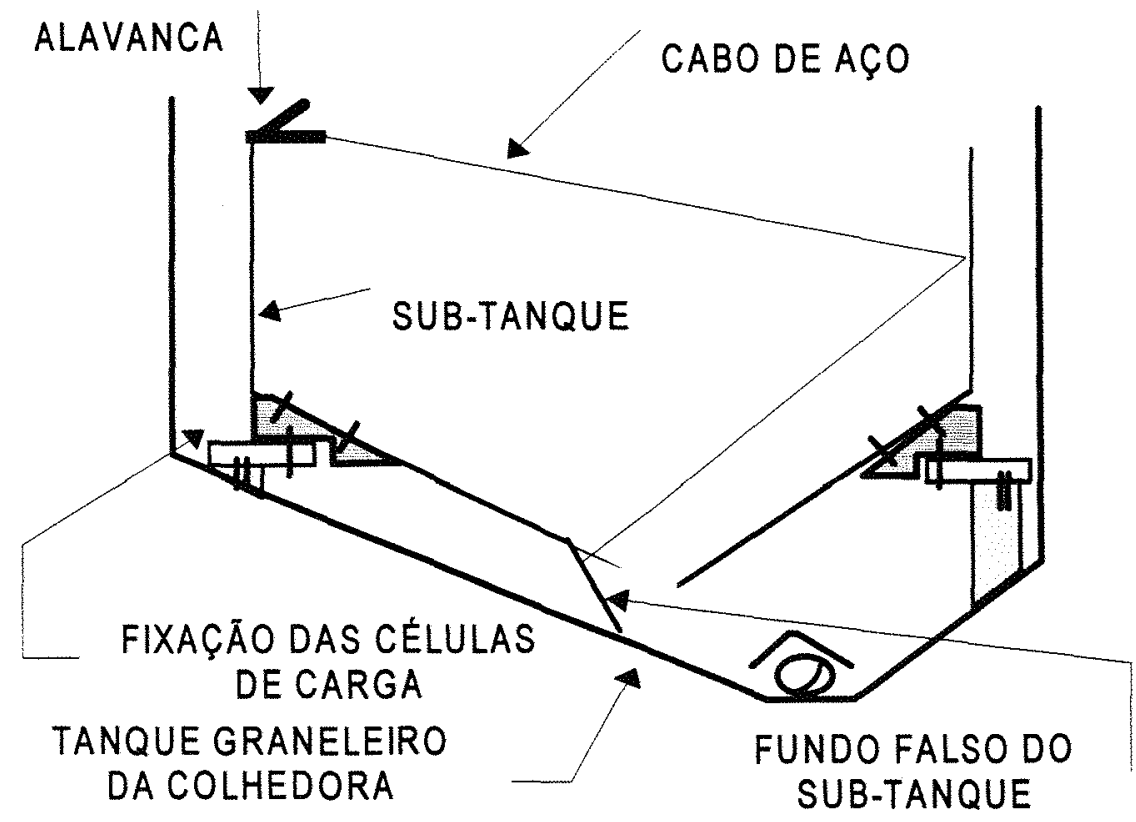

Figura 5. Sistema de monitoramento da produtividade desenvolvido: Esquema de montagem do sub-tanque fixado no interior do tanque graneleiro da colhedora Massey Fergusson modelo 6845 utilizada. 
5,0mm e chapas de aço de $1,9 \mathrm{~mm}$ de espessura, cuja capacidade máxima de armazenamento é de aproximadamente $4905 \mathrm{~N}$ (500kgf), foi montado no interior do tanque graneleiro original da colhedora, sem que nenhuma alteração estrutural fosse realizada.

Uma base de fixação foi projetada e parafusada ao fundo do tanque graneleiro da colhedora, sendo o sub-tanque fixado sobre esta base em apenas 4 pontos, exatamente sobre as 4 células de carga, de forma a ficar completamente apoiado sobre os sensores, sem nenhum outro contato. As células de carga utilizadas possuem capacidade nominal de carga individual de $9810 \mathrm{~N}$ (1000kgf). Um dispositivo de fundo falso, comandado por dois cabos de aço e acionados por meio de uma alavanca foi também construído, a fim de permitir a liberação dos grãos armazenados durante a colheita. A abertura do fundo falso conduz os grãos ao fundo do tanque graneleiro da colhedora, sendo o descarregamento realizado normalmente, através do acionamento do cilindro de descarga da colhedora.

\subsubsection{Sistema de posicionamento global utilizado - GPS.}

Para a localização da colhedora durante a operação, foi utilizado um sistema de DPGS (Sistema de Posicionamento Global Diferencial), composto por dois receptores de GPS, um para a estação base e outro para o posicionamento da colhedora.

Como estação base foi utilizado um receptor marca Trimble modelo "Pathfinder Community BaseStation", composto por uma antena, um receptor de GPS e um computador portátil. Os sinais dos satélites do GPS eram captados pela antena do equipamento e transferidos por meio de um cabo até o receptor, o qual realizava os cálculos de posicionamento. Os dados de posição eram enviados para o computador portátil através de uma porta serial padrão RS-232, sendo lidos por um software especial denominado Pfinder-Pro Community Base Station - PFCBS. Os valores dos 
erros sistemáticos eram calculados pelo software e armazenados no disco rígido do computador portátil, juntamente com os dados de posição.

Para o posicionamento da colhedora durante a operação utilizou-se um receptor móvel, marca Trimble, modelo PRO-XL, o qual foi instalado no interior da cabina da colhedora, sendo sua antena colocada sobre a máquina. O sistema móvel de posicionamento era composto por um receptor de GPS ligado a uma antena e a um coletor de dados, o qual servia também de monitor.

Como no sistema de posicionamento utilizado não havia comunicação entre os receptores móvel e da estação base, a correção diferencial de posicionamento foi realizada em pós-processamento, através do software PfinderPro (PFPRO), fornecido pelo fabricante do GPS. Para o processamento dos dados foi utilizado um microcomputador 486 DX-2 de $66 \mathrm{Mhz}$ de velocidade de processamento e de $16 \mathrm{Mb}$ de memória aleatória volátil (RAM). Além de realizar a correção diferencial de posicionamento, 0 software foi utilizado para converter os arquivos de dados em padrão ASCII. Para o processamento e interpretação dos dados já corrigidos, a partir dos arquivos em padrão texto (ASCII), foi utilizado o software Microsoft Excel(] versão 5.0 e recursos de VBA ("Visual Basic" para aplicativos). Os mapas de produtividade foram criados utilizando-se o programa Surfer $\$$ para Windows versão .5 .01 .

\subsubsection{Sistema de aquisição de dados.}

Um conversor analógico - digital programável, da série micro-P, de fabricação da Electro-Numerics Inc, equipado com um visor digital, filtros digitais e uma saída serial padrão RS-232 foi utilizado para converter os sinais analógicos provenientes das células de carga em valores digitais. Automaticamente após a conversão dos dados, estes eram enviados ao receptor móvel de GPS através de uma porta serial padrăo RS-232. Uma 
vez que o próprio receptor de GPS foi utilizado para a aquisição dos dados, não houve a necessidade da utilização de outro sistema para tal finalidade, fato este que representou grande vantagem e facilidade.

\subsection{Métodos.}

Neste item, são apresentados os procedimentos adotados para a construção e avaliação do sistema automático de pesagem, utilizado para a determinação da produtividade da cultura, bem como os métodos de aquisição e processamento de dados empregados.

\subsubsection{Desenvolvimento, montagem e calibração do sistema de medição da produtividade.}

Inicialmente procedeu-se a montagem e fixação do sub-tanque ao interior do tanque graneleiro da colhedora, parafusando-o sobre as células de carga (sensores), as quais foram posteriormente ligadas eletronicamente em "paralelo", e por um único cabo conectado ao conversor AND.

Após a montagem do sub-tanque graneleiro, foi instalado na colhedora o receptor móvel de GPS, sendo que a antena receptora foi fixada na parte externa da máquina, sobre o centro da tampa do tanque graneleiro, conseqüentemente no centro da colhedora. $O$ conversor analógico-digital foi então ligado ao receptor de GPS, através uma porta serial, padrão RS-232, existente. Posteriormente, foi também conectado ao receptor do GPS o seu coletor de dados. As conexões realizadas entre os equipamentos citados estão esquematizadas na Figura 6.

Após a ligação das células de carga ao conversor, este foi configurado de forma a indicar corretamente a força exercida sobre os 


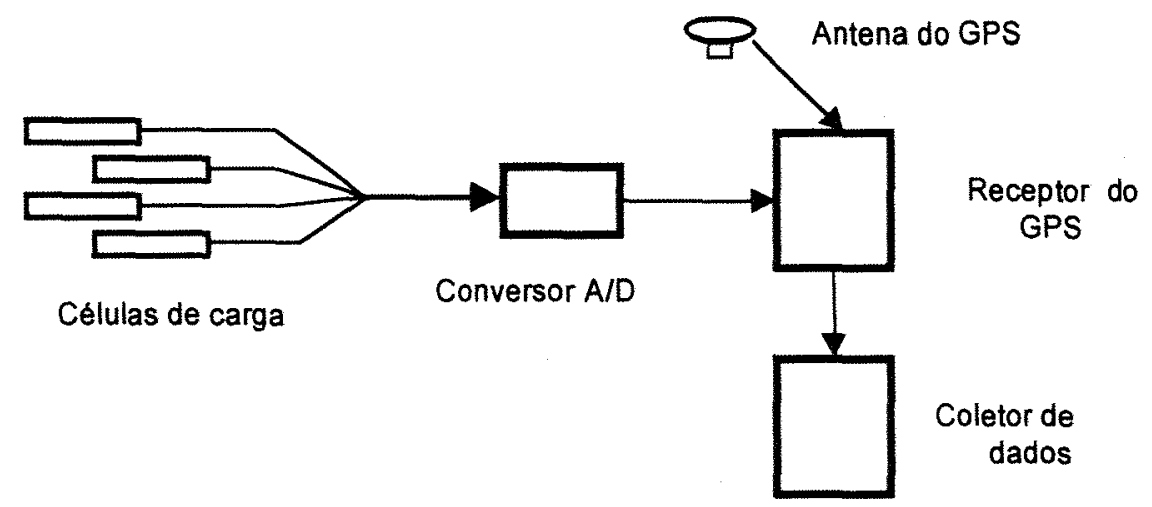

Figura 6. Esquema de conexões do sistema de monitoramento da produtividade desenvolvido. Ligações entre os diversos sistemas e sensores utilizados.

sensores. Foi utilizado também um filtro eletrônico tipo passa baixa, a fim de filtrar os sinais gerados pelos sensores, minimizando os ruídos, sinais acima de $10 \mathrm{~Hz}$, considerados de alta freqüência, gerados pelos mecanismos móveis da colhedora.

Além da filtragem eletrônica, o conversor A/D foi também configurado para realizar uma filtragem digital dos dados de peso. Assim, o conversor analógico-digital calculava um valor filtrado, o qual correspondia numericamente ao valor da média móvel dos últimos dados lidos num determinado intervalo de tempo. Este intervalo foi fixado em 4,8 segundos. Como em cada segundo o conversor realizava 60 leituras, 0 valor filtrado digitalmente corresponde numericamente à média móvel das últimas 288 leituras de peso realizadas.

A fim de verificar a acurácia do sistema de medição construído foram realizados ensaios estáticos e dinâmicos de calibração. Para o ensaio estático foram utilizados pesos padrão de 196,2N (20,0kgf), sendo o sistema de medição da produtividade carregado com estes pesos padrão, partindose do valor $0,0 \mathrm{~N}(0,0 \mathrm{kgf})$ até o limite máximo de 4095,0N (500,0kgf). A cada peso padrăo inserido, foram anotados os valores de carga real e valor de leitura correspondente. Após o carregamento total do sistema, este foi descarregado também a intervalos constantes de 196,2N (20,0kgf), até se atingir $0,0 \mathrm{~N}(0,0 \mathrm{kgf})$. Os dados coletados foram então analisados, sendo 
elaboradas as equações de calibração tanto em carregamento como em descarregamento. $O$ ensaio dinâmico foi realizado a fim de se avaliar 0 comportamento do sistema em condições de operaçăo e verificar a influência das vibrações de baixa freqüência sobre este, causadas principalmente pela movimentação da colhedora. Para tanto, o sistema foi carregado com pesos conhecidos de $981,0 \mathrm{~N} ; 1962,0 \mathrm{~N} ; 2943,0 \mathrm{~N} ; 3924,0 \mathrm{~N}$ e 4905,0N (100kgf, 200kgf, 300kgf, 400kgf e 500kgf, respectivamente.). Para cada valor de peso, a colhedora percorreu uma distância aproximada de $120 \mathrm{~m}$ em linha reta, durante o qual foram realizadas duas aquisições de dados. Na primeira aquisição de dados, o conversor AVD foi configurado para trabalhar utilizando-se apenas a filtragem analógica (filtro tipo passa baixa), e durante a segunda coleta de dados, o conversor foi configurado para realizar uma filtragem digital.

Para a análise dos dados coletados durante o ensaio dinâmico do sistema de medição foram determinados o desvio médio, o erro absoluto médio, o desvio padrão e a amplitude máxima dos dados, conforme ilustra a Tabela 4.

O desvio médio foi utilizado para comparar a diferença entre o valor real de peso acumulado de grãos no interior do sub-tanque e a média aritmética simples dos valores de peso indicados pelo sistema. O erro absoluto médio compara a média dos desvios absolutos das leituras em relação à seu valor real, quantificando assim a amplitude das variações. 0 terceiro parâmetro utilizado (desvio padrăo) mede a dispersão dos dados de uma amostra em relação a seu valor médio, não levando em consideração, portanto, o valor real. A amplitude máxima foi utilizada apenas para indicar um ponto discreto, cujo valor representa a máxima diferença entre o valor real de peso. 
Tabela 4. Parâmetros estatísticos utilizados para a análise dos dados coletados nos ensaios dinâmicos.

\begin{tabular}{|c|c|}
\hline Parâmetro & Interpretação do parâmetro: \\
\hline a) Desvio médio: & $\begin{array}{l}\text { Média aritmética simples dos valores dos desvios } \\
\text { em relação ao peso correto, sendo o desvio a diferença } \\
\text { entre o valor indicado de peso e o valor real existente no } \\
\text { sub-tanque. }\end{array}$ \\
\hline $\begin{array}{l}\text { b) Erro absoluto médio: } \\
\text { Eam }=\frac{\sum|(d-\bar{d})|}{n}\end{array}$ & $\begin{array}{l}\text { É uma medida da dispersão dos dados. } \\
\text { Corresponde a média dos desvios absolutos } \\
\text { (relação entre leitura e peso real) dos dados em relação } \\
\text { ao valor do desvio médio. }\end{array}$ \\
\hline 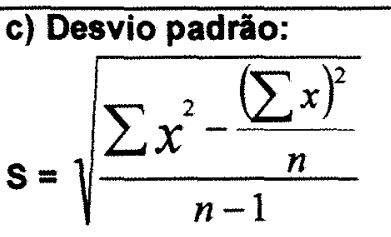 & $\begin{array}{l}\text { Desvio padrão dos dados. } \\
\text { Mede a dispersão dos dados dentro de uma } \\
\text { amostra, indicando assim a variação existente em relação } \\
\text { ao valor médio obtido. }\end{array}$ \\
\hline d) Amplitude máxima: & $\begin{array}{l}\text { Máximo desvio encontrado nos dados em relação } \\
\text { ao valor real. Corresponde à soma dos valores absolutos } \\
\text { do maior desvio acima do valor real e do maior desvio } \\
\text { abaixo do valor real. }\end{array}$ \\
\hline
\end{tabular}

\subsubsection{Configuração do sistema de posicionamento global.}

Após a execução dos ajustes necessários para o funcionamento do sistema de medição, procedeu-se a configuraçăo do sistema de posicionamento global. $O$ receptor da estação base foi configurado de forma a realizar uma leitura de posição a cada 5 segundos, armazenando também neste intervalo as posiçōes correspondentes. O receptor móvel de GPS foi configurado para realizar uma leitura de posiçăo a cada segundo, sendo sua porta serial configurada no mesmo padrão da porta serial do conversor AVD, conforme ilustra a Tabela 5.

De acordo com as características do equipamento do GPS utilizado, as leituras de posição, latitude e longitude, eram realizadas sempre a 
Tabela 5. Parametros de configuração da porta serial (padrão RS-232) do conversor analógico digital.

\begin{tabular}{c|l|c}
\hline "Baud Rate" & - taxa de transmissão em bits por segundo. & 9600 \\
\hline "Parity" & - bit de paridade para verificação de erro. & Nenhum \\
\hline "Data Bit" & - número de bits de um caractere. & 8 \\
\hline "Stop Bit" & - número de bits para determinação do fim do caracter. & 1 \\
\hline "Retry" & - ação a ser tomada em caso de erro. & Nenhuma \\
\hline
\end{tabular}

intervalos de 1 segundo e nos "tempos inteiros", cujos segundos fossem números inteiros. Os dados de peso, enviados pelo conversor $A D D$, eram lidos pelo receptor de GPS nos intervalos existentes entre as leituras de posição e conseqüentemente em tempos não inteiros. Assim, os valores de posição associados à cada valor de peso coletado eram automaticamente interpolados pelo equipamento do GPS, o qual considerava para tais cálculos os valores de posição e tempo coletados.

Para a execução do experimento, ligou-se inicialmente o receptor da estação base do GPS. Após a previa preparação dos equipamentos instalados na colhedora, o fundo falso do sub-tanque foi fechado e travado, procedendo-se então a colheita normalmente, até que fosse colhida uma quantidade próxima, porém sempre inferior a $4905 \mathrm{~N}(500,0 \mathrm{kgf})$. O processo de colheita e de aquisição dos dados era então interrompido, o fundo falso do sub-tanque era aberto e o material colhido transferido à uma carreta. $O$ fundo falso era novamente fechado e travado, e um novo ciclo de medição era iniciado. A colheita de toda a área experimental foi realizada seguindo-se este procedimento.

\subsubsection{Verificação da acurácia do sistema de GPS utilizado.}

De acordo com vários autores, como por exemplo Han et. al. (1994) e Stafford (1996a), a acurácia do sistema de GPS utilizado é importante para que a localização dos dados levantados seja confiável, sendo considerada de fundamental importância para este trabalho. 
Para a determinação da acurácia estática do sistema de DGPS utilizado, foram demarcados um total de 11 pontos, cujas coordenadas geográficas foram previamente calculadas. A determinação das coordenadas geográficas destes pontos considerados foi realizada através de metodologia topográfica convencional, utilizando-se de um distanciômetro eletrônico, cuja acurácia era superior a 0,01metros.

O receptor móvel de GPS foi então estacionado sobre cada um dos pontos, para os quais foram realizadas 59 leituras de posição, a uma taxa de uma leitura por segundo

As coordenadas geográficas de cada um dos 11 pontos, calculadas com o receptor móvel, foram estatisticamente comparadas com as coordenadas obtidas através do método topográfico convencional, consideradas coordenadas reais.

Para a determinação da acurácia do sistema de GPS utilizado foram consideradas apenas as coordenadas geográficas diferencialmente corrigidas, uma vez que em todo o trabalho somente foram utilizados os valores de posição já corrigidos.

\subsubsection{Correção diferencial de posição.}

Os dados coletados em campo, armazenados no coletor de dados do GPS móvel, foram transferidos para um microcomputador, gravados como arquivos de extensão .SSF, compativeis apenas com o software do GPS. Ao final do dia, além dos dados coletados em campo, foram também transferidos os arquivos de posição e erros sistemáticos, coletados pelo receptor de GPS da estação base. Através da utilização do software PfinderPro (PFPRO), realizou-se a correção diferencial das posições coletadas em campo. Os dados coletados durante a colheita já com suas posições corrigidas foram salvos em arquivos com extensão .COR, e posteriormente processados e transformados em arquivos de padrão ASCII, gravados com 
extensão .ASC. Estes últimos arquivos continham as informações de latitude, longitude e peso acumulado de grãos no interior do sub-tanque graneleiro, foram então transformados em planilhas eletrônicas do software Microsoft Excel@ 5.0. Ao todo foram criadas 6 planilhas eletrônicas, cada uma das quais correspondendo a um talhão para cada um dos quais foram elaborados gráficos referentes ao caminhamento da colhedora no campo (longitude no eixo $x$ e latitude no eixo y) a fim de certificar-se que a correção diferencial dos valores de posição fora realizada corretamente.

\subsubsection{Correção de posicionamento em função do tempo de processamento do material colhido (grãos).}

O tempo de processamento do material colhido, dado pela soma dos tempos necessários para a extração da espiga pela plataforma, condução do material até o sistema de trilha, limpeza e transporte dos grãos até 0 subtanque, ocasiona um atraso entre os valores de peso coletados e as posiçōes reais a eles associados. Devido a este atraso, cada valor de peso coletado corresponde à quantidade de material colhido em uma posição anterior àquele momento, proporcional ao tempo e à velocidade de deslocamento da colhedora. Assim, para corrigir este deslocamento de posição, foi realizado inicialmente um ensaio para determinar qual era o tempo médio de processamento do material pela colhedora para que 0 atraso existente entre os valores de peso e posiçăo pudesse ser posteriormente corrigido.

Para a determinação deste tempo médio, a colhedora foi colocada em funcionamento até que todos os mecanismos estivessem sem a presença de grãos. A máquina foi então deslocada em velocidade normal de operação em direção às linhas de milho. No momento em que as primeiras plantas eram tocadas pela plataforma, disparava-se um cronômetro, o qual era paralisado assim que os primeiros grãos atingissem o sub-tanque graneleiro. 
Este procedimento foi executado por 6 vezes, sendo considerado como tempo de atraso referente ao processamento o valor da média aritmética simples dos tempos obtidos nas 6 repetiçōes realizadas.

Uma vez determinado o tempo médio de atraso no processamento do material colhido, os dados coletados foram corrigidos, deslocando-se cada um dos valores de peso em uma distância proporcional ao tempo médio de atraso.

\subsubsection{Divisão da área em "células".}

A agricultura de precisão baseia-se na existência de unidades gerenciais básicas, denominadas células, cujas características são consideradas homogêneas. Assim, para a sub-divisão da área experimental em células, determinou-se inicialmente os pontos representativos, a partir dos quais foram identificadas as células e suas respectivas produtividades.

\subsubsection{Determinação do ponto representativo e do centro das células.}

Os sistemas de medição da produtividade descritos na bibliografia foram projetados de modo a fornecer instantaneamente a produtividade da cultura. Como o sistema desenvolvido neste trabalho media diretamente o peso acumulado dos grãos no interior do sub-tanque, a produtividade somente pode ser calculada posteriormente, a partir da diferença de peso total acumulado no interior do sub-tanque graneleiro existente entre dois pontos consecutivos.

Estando a colhedora sujeita à vibrações de baixa freqüência, as quais podem diminuir momentaneamente a acurácia do valor de peso fornecido pelo sistema de medição, ao invés de se utilizar todos os dados de peso e 
posição coletados ponto a ponto, optou-se por dividir a área em células de $3,6 \mathrm{~m}$ de largura (largura da plataforma) por 10,8m de comprimento ( 3 vezes a largura), calculando-se para cada uma um único valor de peso acumulado, dado representado pela média aritmética simples de todos os valores de peso realizados nos limites da célula em questão.

Assim, partindo-se do início de cada linha de colheita, e a espaços regulares de $10,8 \mathrm{~m}$, foram calculadas as coordenadas geográficas limitrofes de cada célula a ser criada, as quais foram posteriormente identificadas pelos seu respectivo ponto central. Para cada uma das células criadas, foi então determinado um ponto representativo, conforme ilustra a Figura 7 , cujos valores de latitude e longitude representam a média aritmética simples

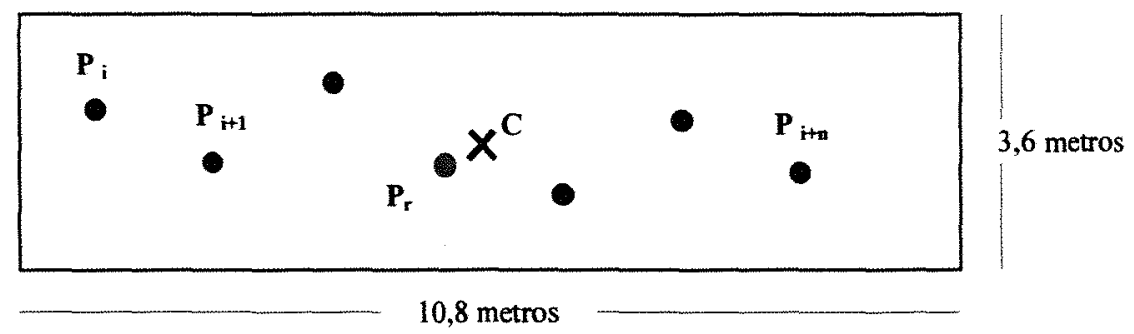

Figura 7. Representação gráfica ilustrativa da célula, apresentando a metodologia para determinação do "ponto representativo" $\left(P_{r}\right)$.

Em que:

$\mathrm{Pi}=$ Ponto $\mathrm{i}$ de leitura do sistema de medição de produtividade, contendo dados de latitude, longitude e peso acumulado.

$\mathrm{Pr} \quad=$ Ponto representativo.

C = Centro geográfico da célula.

dos valores de latitude e longitude de todos os pontos localizados nos limites da célula considerada. Da mesma forma, o respectivo valor de peso acumulado foi obtido através da média aritmética dos valores individuais de peso de cada um dos pontos considerados para o cálculo do ponto representativo. Desta forma, cada célula passa a ser representada por um único par de coordenadas, latitude e longitude, e por um único valor de peso acumulado. 


\subsubsection{Cálculo da produtividade.}

Após a determinação dos pontos representativos das células, os quais continham os valore de peso acumulado de grãos no interior do sub-tanque graneleiro, foram determinados as produtividades individuais de cada célula.

Inicialmente, foram determinadas as distâncias entre os pontos representativos de duas células consecutivas, através da seguinte equaçăo.

$$
d=\sqrt{\left(\mathrm{Lt}_{i+1}-\mathrm{Lt}_{i}\right)^{2}+\left(\mathrm{Lg}_{i+1}-\mathrm{Lg}_{i}\right)^{2}}
$$

Em que:

d = Distância entre os pontos representativos $\left(P_{r}\right)$ de duas células consecutivas.

$\mathrm{Lt}_{i+1}=$ Latitude do $\mathrm{P}_{\mathrm{r}}$ da célula $\mathrm{I}_{i+1}$

$\mathrm{Lt}_{i} \quad=$ Latitude do $\mathrm{P}_{\mathrm{r}}$ da célula ${ }_{i}$

$\mathrm{Lg}_{\mathrm{r}+1}=$ Longitude do $\mathrm{P}_{\mathrm{r}}$ da célula ${ }_{t+1}$

$\mathrm{Lg}_{i} \quad=$ Longitude do $\mathrm{P}_{\mathrm{r}}$ da célula ${ }_{1}$

Posteriormente, foram calculadas as quantidades lineares $(\mathrm{Kg} / \mathrm{m})$ a partir da distância entre dois pontos representativos consecutivos e da quantidade de grãos colhidos durante este percurso, calculada a partir da diferença dos respectivos valores de peso acumulado nos respectivos pontos, a partir da equação ( 2 ).

$\mathbf{Y}_{i}=\frac{\left(W_{i+1}\right)-\left(W_{i}\right)}{d_{i}}$

onde:

$Y_{i} \quad=$ Quantidade linear índice $\mathrm{I}$. (Kgf/m)

$W_{i+1}=$ Peso acumulado no $P_{r}$ da célula ${ }_{i+1}(\mathrm{Kgf})$

$W_{i} \quad=$ Peso acumulado no $\mathrm{P}_{\mathrm{r}}$ de céluila ${ }_{i}(\mathrm{Kgf})$

$d_{i} \quad=$ Distância entre os $P_{r}(m)$

Após a determinação das quantidades lineares, foram identificadas as distâncias existentes entre os limites das células e seu respectivo ponto representativo, conforme ilustram as distâncias $d_{1 a}, d_{1 b}, d_{2 a}$ e $d_{2 b}$, indicadas 
na Figura 8. Assim, a produtividade de cada célula foi calculada através da equação 3 , a qual considera a relação entre a quantidade total de grãos colhidos e sua área, $\left(3,6 \mathrm{~m} \times 10,8 \mathrm{~m}=38,88 \mathrm{~m}^{2}\right)$

$P_{i+1}=\left(Y_{1 b}+Y_{2 a}\right) \times \frac{10}{3,6 \times 10,8}$

sendo :

$Y_{1 b}=\frac{Y_{1}}{d_{1}} \times d_{1 b} \quad$ e $\quad Y_{2 a}=\frac{Y_{2}}{d_{2}} \times d_{2 a}$

Em que:

$\mathrm{Pi}+1=$ Produtividade da célula $\mathrm{i}+1$. (toneladas)

$\mathrm{Y} 1 \mathrm{~b}=$ Quantidade linear no trecho d1b $(\mathrm{Kgf})$

Y2a = Quantidade linear no trecho d2a (Kgf)
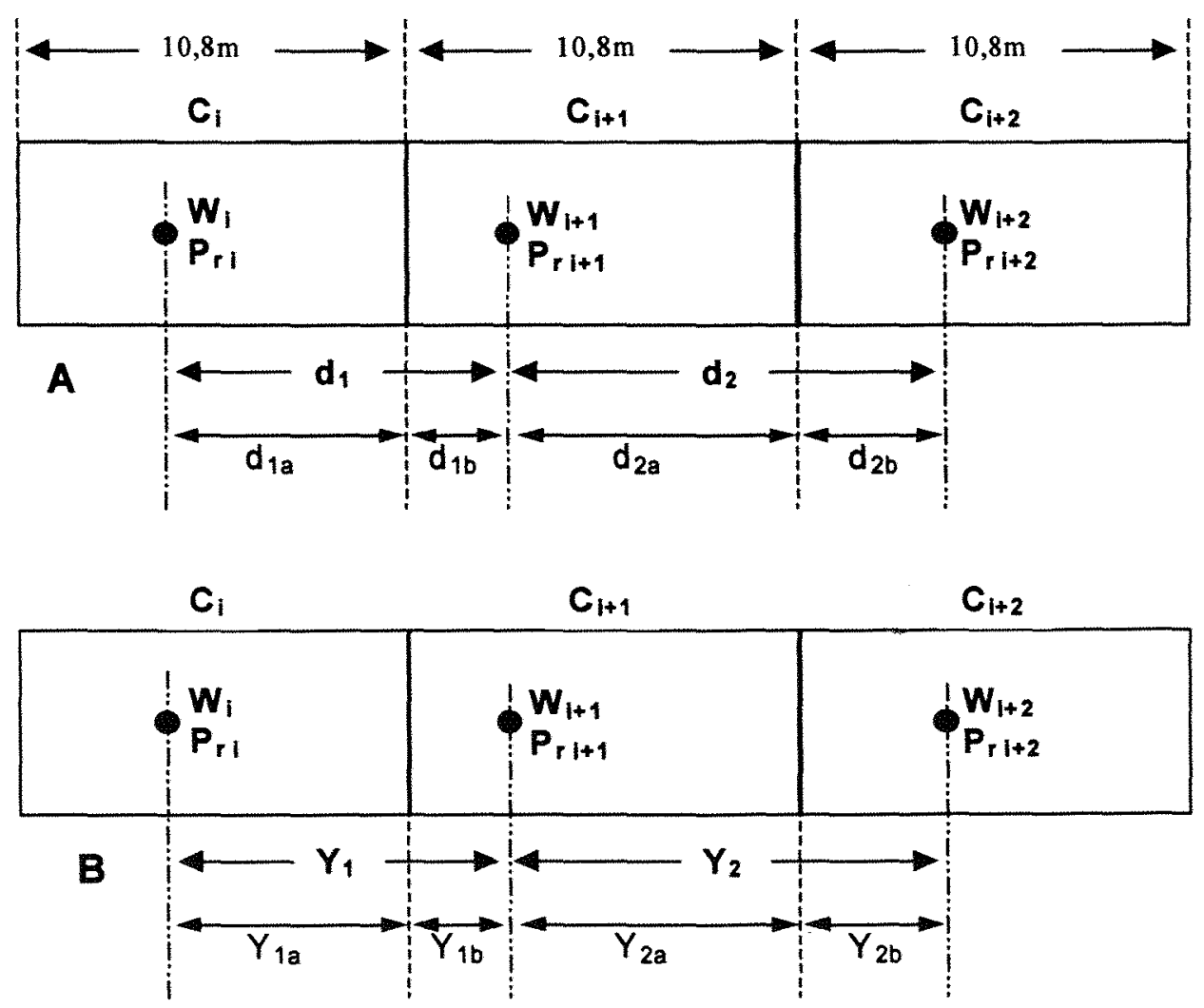

Figura 8. Determinação da produtividade das células.

Em que:

$C_{i}=$ Célula $i$

$d$ = Distância entre os pontos indicados.

$W_{i}=$ Peso acumulado no ponto $i$

$Y=$ Quantidade linear $(\mathrm{Kg} / \mathrm{m})$ no trecho indicado. 


\section{RESULTADOS E DISCUSSÃO.}

Antes da realização do monitoramento da produtividade, foram avaliados o sistema de medição da produtividade e o sistema de posicionamento geográfico utilizados. Somente após a avaliação destes equipamentos o mapeamento da produtividade foi realizado. Assim, inicialmente apresentam-se os resultados obtidos a partir da avaliação destes sistemas e posteriormente os resultados do monitoramento da produtividade.

\subsection{Sistema de medição da produtividade - calibração estática.}

O sistema automático de pesagem, desenvolvido para a medição direta do peso de grãos colhidos foi submetido a um teste estático, a fim de verificar seu funcionamento. Foi realizada desta forma a calibraçăo deste sistema tanto em carregamento quanto em descarregamento, representadas pelas seguintes equações matemáticas:

\section{CARREGAMENTO}

$y=1,0001 x-1,4925(N)$

$y=1,0001 x-0,1521(\mathrm{kgf})$

onde:

$y=$ peso indicado pelo sistema de mediçăo.

$x=$ valor real do peso no interior do sub-tanque graneleiro.

\section{DESCARREGAMENTO}

$$
\begin{aligned}
& y=1,0007 x-1,2493(N) \\
& y=1,0007 x-0,1274(\mathrm{kgf})
\end{aligned}
$$


A representação gráfica da curva de calibração para o sistema em carregamento é ilustrada através do gráfico da Figura 9.

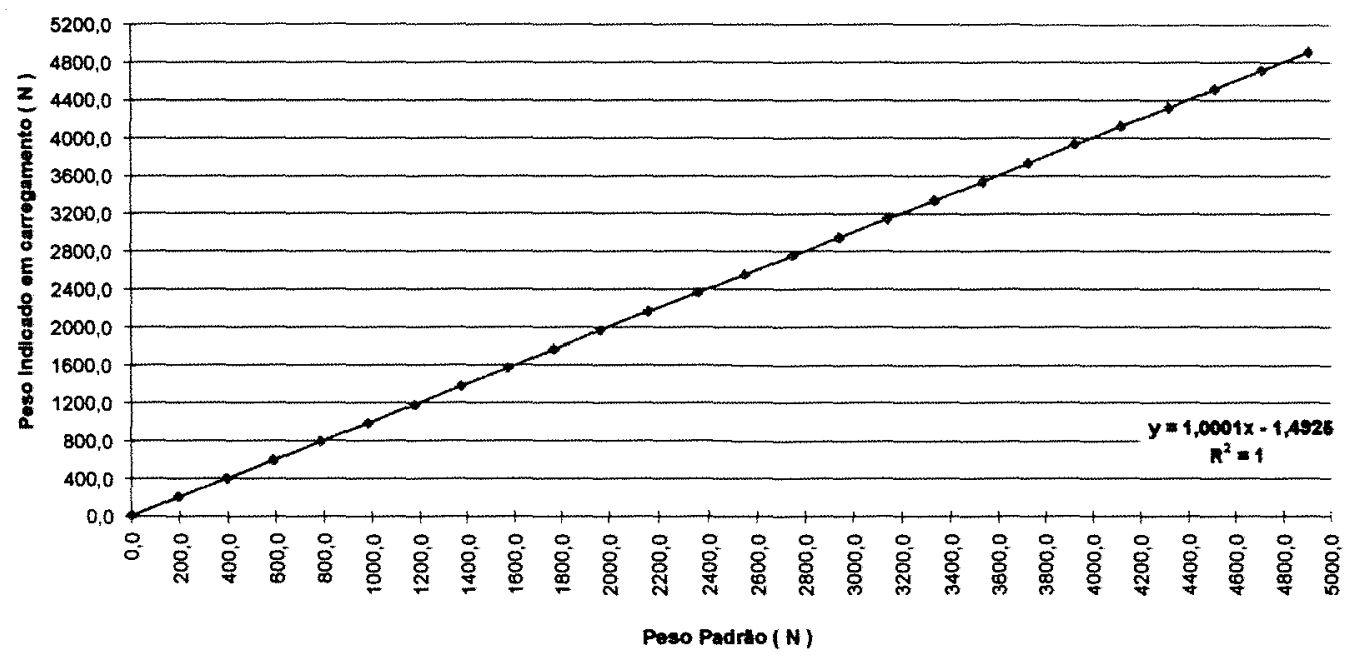

Figura 9. Equação de calibraçăo obtida para o sistema de medição da produtividade. Sistema em regime de carregamento.

Uma vez que o sistema foi construído para operar apenas em carregamento, durante a colheita de grãos, estudos mais detalhados de seu comportamento somente foram realizados para esta condição. Desta forma, os limites estatísticos de erro $\left(\mathrm{S}_{\mathrm{qo}}\right)$ obtidos para o sistema em carregamento, ainda em condições estáticas, foi de $3,99 \mathrm{~N}(0,41 \mathrm{kgf})$, para uma probabilidade de $99,7 \%$. O maior valor de erro obtido foi de $5,886 \mathrm{~N}$ $(0,600 \mathrm{Kgf})$.

Com relação à umidade e a densidade dos grãos colhidos, Baerdemaeker et. al. (1985) afirmaram que os sistema de medição de produtividade baseados na determinação do fluxo de massa são influenciados pela a umidade e densidade dos grãos, bem como pelo fluxo médio da massa, os quais são responsáveis pela introdução de erros na determinação da produtividade. Auernhammer et. al. (1994) afirmaram ainda que o sistema volumétrico de medição de produtividade por eles desenvolvido, foi particularmente influenciado pela variação da umidade e da 
densidade dos grãos, uma vez que o peso de um determinado material é proporcional à sua densidade, a qual é afetada pela umidade dos grãos.

Devido ao fato do sistema de medição desenvolvido neste trabalho realizar a pesagem direta dos grãos, não houve a necessidade de se determinar a umidade ou a densidade dos grãos, como nos casos dos sistemas citados anteriormente. A não necessidade da medição da umidade e densidade dos grãos é notoriamente uma das vantagens do presente sistema.

\subsection{Sistema de medição da produtividade - calibração dinâmica.}

Durante a colheita, o sistema de medição opera sob os efeitos de inúmeras fontes de vibração. Para se evitar seus efeitos, optou-se pela utilização de duas filtragens distintas, uma analógica, realizada através de um filtro eletrônico tipo passa baixa, e uma segunda filtragem digital. A fim de avaliar a eficácia desta filtragem digital, avaliou-se o comportamento do sistema operando inicialmente sem a utilização desta e posteriormente com a filtragem, obtendo-se os seguintes resultados:

O maior valor de desvio médio calculado para o ensaio sem a filtragem digital foi igual a $12,86 \mathrm{~N}(1,31 \mathrm{kgf})$, obtido no instante em que o peso total de grãos no interior do sub-tanque graneleiro era de $4905 \mathrm{~N}$ (500kgf), representando-se assim uma variação de $0,262 \%$ em relação ao peso real. O segundo maior valor de desvio médio foi de $5,07 \mathrm{~N}(0,52 \mathrm{kgf})$, obtido com $1962 \mathrm{~N}$ (200kgf) de peso no sub-tanque, correspondendo a uma variação de $0,258 \%$ em relação ao peso real existente. Já a maior variação percentual obtida foi de $0,289 \%$ em relação ao peso real, correspondendo assim a um desvio médio de $2,84 \mathrm{~N}(0,29 \mathrm{kgf})$ para um total de $981 \mathrm{~N}$ (100kgf) no interior do sub-tanque.

Os resultados da análise estatística realizada para os dados coletados sem a filtragem digital estão ilustrados na Tabela 6. 
Tabela 6. Análise estatística para o ensaio dinâmico do sistema de medição da produtividade sem a utilização da filtragem digital.

\begin{tabular}{l|r|r|r|r|r}
\hline \multicolumn{1}{c|}{ Parâmetros } & \multicolumn{5}{c}{ Pesos } \\
\cline { 2 - 6 } \multicolumn{1}{c|}{ Estatísticos utilizados. } & $981 \mathrm{~N}$ & $1962 \mathrm{~N}$ & $2943 \mathrm{~N}$ & $3924 \mathrm{~N}$ & $\mathbf{4 9 0 5 N}$ \\
\hline Desvio médio. & $-2,84$ & $-5,07$ & 1,83 & $-2,31$ & 12,86 \\
\hline Erro absoluto médio. & 17,81 & 27,68 & 35,87 & 43,26 & 46,68 \\
\hline Desvio Padrắo. & 23,15 & 36,15 & 51,38 & 61,73 & 58,71 \\
\hline
\end{tabular}

Para o ensaio realizado com a filtragem digital, o máximo desvio médio obtido foi de $2,01 \mathrm{~N}(0,21 \mathrm{kgf})$, para um total de $1943 \mathrm{~N}$ (300kgf) no interior do sub-tanque, o que representou uma variação percentual de $0,068 \%$ em relação ao peso real existente. O maior desvio médio percentual foi de $0,186 \%$, representado pela desvio médio de $1,83 \mathrm{~N}(0,19 \mathrm{~kg} f)$ ocorrido para um peso total de $981 \mathrm{~N}$ (100kgf).

Os resultados da análise estatística realizada para os dados coletados com a filtragem digital encontram-se na Tabela 7.

Tabela 7. Análise estatística para o ensaio dinâmico do sistema de medição da produtividade com a utilizaçăo da filtragem digital.

\begin{tabular}{l|r|r|r|r|r}
\hline \multirow{2}{*}{ Parâmetros } & \multicolumn{5}{c}{ Pes0s } \\
\cline { 2 - 6 } \multicolumn{1}{c|}{ Estatísticos utilizados } & $\mathbf{9 8 1 N}$ & $\mathbf{1 9 6 2 N}$ & $\mathbf{2 9 4 3 N}$ & $\mathbf{3 9 2 4 N}$ & $\mathbf{4 9 0 5 N}$ \\
\hline Desvio médio. & 1,83 & $-1,01$ & 2,01 & 0,96 & $-0,72$ \\
\hline Erro absoluto médio. & 0,98 & 3,76 & 2,79 & 10,56 & 4,42 \\
\hline Desvio Padrão. & 1,24 & 15,18 & 6,56 & 34,40 & 10,53 \\
\hline
\end{tabular}

A redução da variação percentual máxima de $0,289 \%$ para $0,186 \%$, proporcionada pela filtragem digital dos dados, representou uma diminuição de $64,36 \%$ na amplitude de variação dos valores indicados pelo sistema de medição da produtividade.

Outro parâmetro utilizado para medir a dispersão dos dados foi o desvio padrão da amostra. Para os dados não filtrados digitalmente, o maior desvio padrão obtido foi de $61,73 \mathrm{~N}(6,29 \mathrm{~kg})$, para um peso total no interior do sub-tanque de $3924 \mathrm{~N}$ (400kgf). Para os dados filtrados digitalmente, 0 maior valor de desvio padrão obtido foi de $34,4 \mathrm{~N}(3,51 \mathrm{~kg} f)$, também para o peso de $3924 \mathrm{~N}$ (400kgf). 
A eficácia da filtragem digital utilizada pode ser finalmente comprovada através da análise e comparação do erro absoluto médio calculados para os ensaios sem e com uso da filtragem digital. O menor valor de erro absoluto médio para o ensaio sem a filtragem digital foi de $17,81 \mathrm{~N}(1,82 \mathrm{kgf})$, obtido para o peso de $981 \mathrm{~N}$ (100kgf) e o maior valor foi obtido para o peso de $4905 \mathrm{~N}$ (500kgf), foi de $46,68 \mathrm{~N}(4,76 \mathrm{kgf})$.

Para o ensaio com a filtragem digital, o maior valor de erro absoluto médio obtido foi de $10,56 \mathrm{~N}(1,08)$, obtido para o peso total de $3924 \mathrm{~N}$ (400kgf). Nota-se que o maior valor de erro absoluto médio obtido para o ensaio realizado com a filtragem digital foi $40,70 \%$ menor que o menor valor obtido sem a filtragem digital, indicando claramente que a filtragem digital contribuiu significativamente para a redução da dispersão dos dados.

A eficácia da filtragem digital dos dados pode ser mais facilmente visualizada através da análise do gráfico ilustrado pela Figura 10 , no qual os

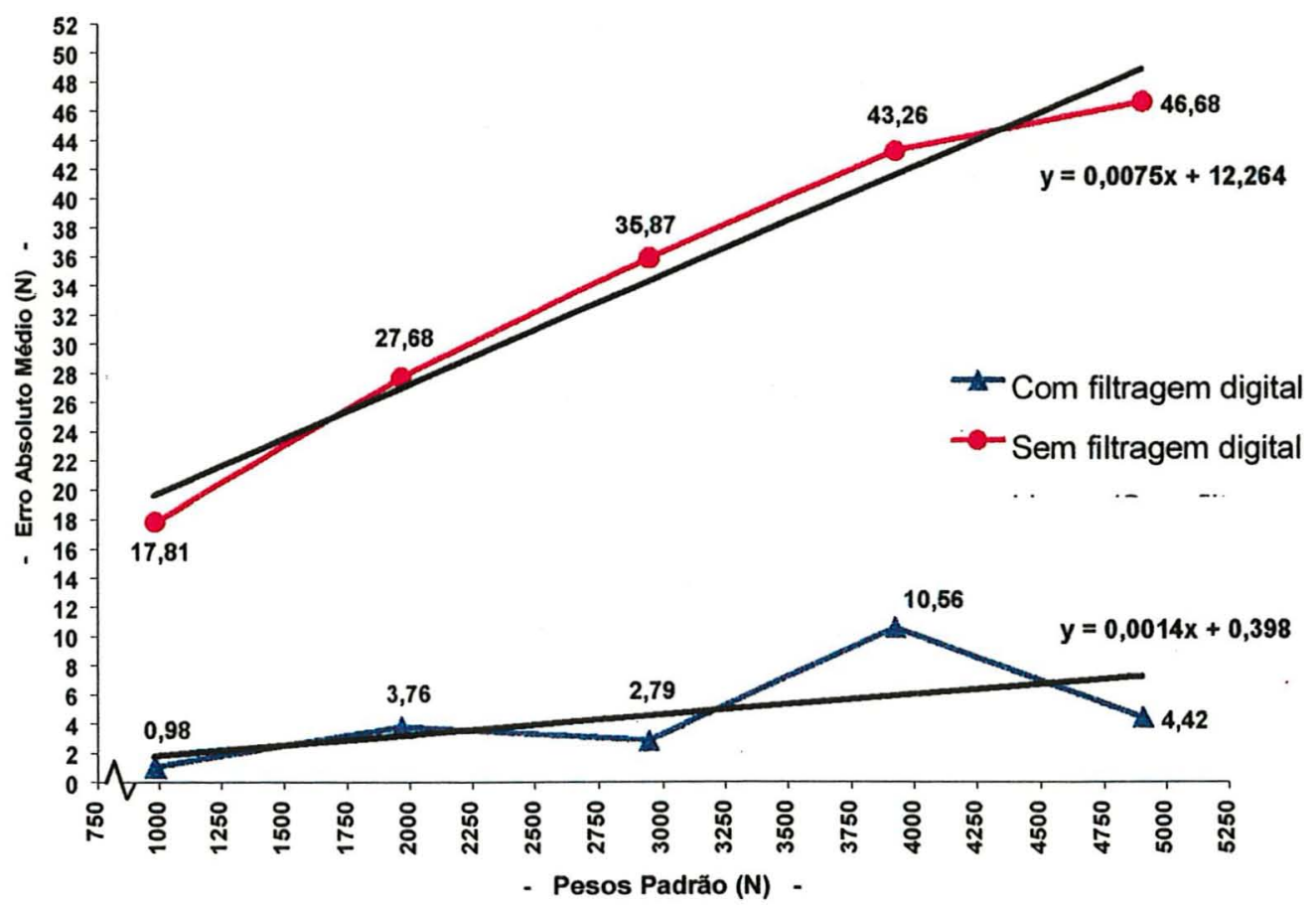

Figura 10. Valores de erro absoluto médio obtidos nos ensaios dinâmicos do sistema de medição da produtividade com e sem a filtragem digital dos dados. 
valores de erro médio absoluto obtidos para os ensaios dinâmicos do sistema de medição realizados com e sem a filtragem digital são apresentados.

Os coeficientes angulares, calculados a partir da regressão linear dos valores de erro absoluto médio, foram iguais a 0,0075 e 0,0014 , respectivamente para os ensaios com e sem filtragem digital, sendo este último 5,36 vezes menor que o primeiro. Quanto maior o coeficiente angular, tanto maior a relação entre a variação do valor de peso indicado pelo sistema e o peso total existente no sub-tanque.

\subsection{Aquisição dos dados de posição e peso.}

Após realizada a correção diferencial dos pontos, cada um dos arquivos foram transformados para padrão texto (ASCII), os quais continham os dados de longitude, latitude, horário de aquisição das coordenadas e peso acumulado, dispostos em 4 colunas, conforme ilustra a Tabela 8, na qual apresenta-se uma parte dos dados originais, anterior à realização de qualquer processamento. Os dados de posição e horário aparecem separados por um caracter especial $(" m)$ e os dados de peso com 3 caracteres especiais de terminação ("10d").

Devido às características do equipamento receptor de GPS, os dados de posição eram coletados nos "intervalos inteiros" de horário, a uma razão exata de 1 dado a cada segundo. Os dados de peso eram registrados, então, em intervalos de aproximadamente 1 segundo, sendo que os valores de longitude e latitude associados eram automaticamente calculados pelo próprio receptor de GPS. 
Tabela 8. Estrutura dos arquivos de dados após correção diferencial e transformação para padrão ASCII. (dados originais).

\begin{tabular}{|c|c|c|c|}
\hline Longitude & Latitude & Horário & Peso \\
\hline $\begin{array}{r}7485372,701805 \\
7485372,760754 \\
7485371,854943 \\
7485371,994380 \\
7485370,923032 \\
7485371,201343 \\
7485369,951570 \\
7485370,357144 \\
7485369,036008 \\
7485369,518337 \\
7485368,690190 \\
7485367,995992 \\
7485367,919801 \\
7485366,892184 \\
7485367,082466 \\
7485366,226191 \\
7485366,216680 \\
7485365,091985 \\
7485365,347370 \\
7485364,318338 \\
7485364,517373 \\
:\end{array}$ & $\begin{array}{l}232363,979685 \\
232363,967970 \\
232364,150875 \\
232364,120271 \\
232364,354628 \\
232364,294328 \\
232364,551827 \\
232364,477235 \\
232364,731675 \\
232364,631505 \\
232364,803494 \\
232364,895087 \\
232364,905140 \\
232365,105278 \\
232365,066455 \\
232365,241158 \\
232365,243099 \\
232365,343302 \\
232365,313917 \\
232365,440630 \\
232365,409419\end{array}$ & $\begin{array}{l}12: 03: 52,07 \\
12: 03: 52,00 \\
12: 03: 53,17 \\
12: 03: 53,00 \\
12: 03: 54,33 \\
12: 03: 54,00 \\
12: 03: 55,48 \\
12: 03: 55,00 \\
12: 03: 56,58 \\
12: 03: 56,00 \\
12: 03: 57,00 \\
12: 03: 57,90 \\
12: 03: 58,00 \\
12: 03: 59,22 \\
12: 03: 59,00 \\
12: 03: 59,98 \\
12: 04: 00,00 \\
12: 04: 01,30 \\
12: 04: 01,00 \\
12: 04: 02,24 \\
12: 04: 02,00\end{array}$ & $\begin{array}{l}0001,410 d \\
0001,410 d \\
0001,410 d \\
0001,410 d \\
0001,510 d \\
0001,510 d \\
0001,610 d \\
0001,910 d \\
0002,210 d \\
0002,610 d\end{array}$ \\
\hline
\end{tabular}

\subsection{Acurácia do sistema de GPS.}

Os valores das coordenadas geográficas, latitude e longitude, calculados para os 11 pontos através de método topográfico convencional e através do GPS são ilustrados na Tabela 9, bem como a comparação entre os valores de posição calculados através dos dois métodos, dados pela distância entre as duas posições.

A diferença média entre as posições calculadas pelo distanciômetro eletrônico e pelo GPS foi de $0,605 \mathrm{~m}$, considerando-se todos os pontos. A máxima diferença entre a posição real e a posição dada pelo GPS foi de $1,255 \mathrm{~m}$, obtida no ponto B13. A menor diferença entre as posições, cuja distância foi de apenas $0,105 \mathrm{~m}$, foi obtida para o ponto M01.

Analisando-se os dados da Tabela 9 pode-se notar que $36,3 \%$ dos pontos apresentaram um erro menor que $0,45 \mathrm{~m}$ referente a distância entre as posições indicadas pelos dois métodos distintos. Isto ocorreu para os 
pontos B08, B14, B16 e M01, os quais apresentaram diferenças de posicionamento de respectivamente $0,413 \mathrm{~m}, 0,253 \mathrm{~m}, 0,420 \mathrm{~m}$ e $0,105 \mathrm{~m}$. Pode-se notar ainda que $90,9 \%$ dos 11 pontos considerados apresentaram diferença de posição entre coordenada real e média inferior a 1,0m. Dos 11 pontos considerados, apelas 1 ponto apresentou erro maior que $1,0 \mathrm{~m}$.

Tabela 9. Coordenadas geográficas determinadas através de método convencional de topografia, com utilização de distanciômetro eletrônico e através de GPS.

\begin{tabular}{c|c|c|c|c|c}
\hline Ponto & $\begin{array}{c}\text { Coordenadas Geográficas } \\
\text { Reais Levantamento } \\
\text { Distanciométrico } \\
\text { (UTM) }\end{array}$ & $\begin{array}{c}\text { Coordenadas Indicadas pelo } \\
\text { GPS } \\
\text { Média de 59 leituras } \\
\text { (UTM) }\end{array}$ & $\begin{array}{c}\text { Distáncia entre } \\
\text { coordenada } \\
\text { real e média }\end{array}$ \\
\cline { 2 - 6 } & Longitude & Latitude & Longitude & Latitude & $(\mathbf{m}$ ) \\
\hline B00 & 7486188,925 & 229611,531 & 7486188,823 & 229612,2606 & 0,737 \\
\hline B05 & 7486777,925 & 230333,450 & 7486777,842 & 230332,6244 & 0,830 \\
\hline B07 & 7486891,404 & 230518,781 & 7486891,705 & 230518,2061 & 0,649 \\
\hline B08 & 7486272,702 & 231021,956 & 7486272,289 & 231021,9634 & 0,413 \\
\hline B09 & 7485882,316 & 231221,264 & 7485882,979 & 231221,4452 & 0,687 \\
\hline B10 & 7485535,245 & 231273,524 & 7485535,683 & 231273,8181 & 0,528 \\
\hline B13 & 7485560,200 & 230224,762 & 7485560,506 & 230225,9785 & 1,255 \\
\hline B14 & 7485772,165 & 230000,072 & 7485771,935 & 230000,1781 & 0,253 \\
\hline B16 & 7486031,421 & 229848,798 & 7486031,764 & 229848,5547 & 0,420 \\
\hline M01 & 7486511,646 & 230778,626 & 7486511,734 & 230778,5685 & 0,105 \\
\hline M02 & 7486930,299 & 230538,887 & 7486930,251 & 230538,1108 & 0,778 \\
\hline Média & - & - & - & - & 0,605 \\
\hline
\end{tabular}

Pode-se verificar, de acordo com a Tabela 10, que a menor distância entre uma posição individual e a posição de coordenadas médias, para o ponto $\mathrm{BOO}$ foi de $0,060 \mathrm{~m}(6,0 \mathrm{~cm})$. Para este mesmo ponto, entretanto, o ponto mais distante da posição de coordenadas médias encontrava-se a $0,530 \mathrm{~m}(53,0 \mathrm{~cm})$, sendo que a média das distâncias entre cada um das posições individuais e a posição de coordenadas médias foi, para o ponto B00, de 0,296m $(29,60 \mathrm{~cm})$.

Considerando-se todos os 11 pontos (B00, B05, ..., M02), pode-se verificar que o valor médios das distâncias mínimas, máximas e médias entre posições individuais e a posição média foram de $0,021 \mathrm{~m}$ e 0,224 e $0,109 \mathrm{~m}$, respectivamente. 
Tabela 10. Comparação das distâncias $(m)$ entre posiçōes individuais indicadas pelo GPS e a respectiva posição média do ponto.

\begin{tabular}{c|c|c|c|c|c|c}
\hline Ponto & Mínima & Máxima & Média & Variância & $\begin{array}{c}\text { Desvio } \\
\text { Padrão }\end{array}$ & $\begin{array}{c}\text { Desvio } \\
\text { Médio }\end{array}$ \\
\hline $\mathbf{B 0 0}$ & 0,060 & 0,530 & 0,296 & 0,012 & 0,106 & 0,088 \\
\hline $\mathbf{B 0 5}$ & 0,014 & 0,191 & 0,092 & 0,002 & 0,047 & 0,040 \\
\hline B07 & 0,015 & 0,321 & 0,124 & 0,005 & 0,066 & 0,056 \\
\hline B08 & 0,001 & 0,081 & 0,040 & 0,000 & 0,021 & 0,018 \\
\hline B09 & 0,008 & 0,126 & 0,060 & 0,001 & 0,034 & 0,029 \\
\hline B10 & 0,004 & 0,146 & 0,036 & 0,001 & 0,027 & 0,017 \\
\hline B13 & 0,034 & 0,324 & 0,167 & 0,004 & 0,060 & 0,050 \\
\hline B14 & 0,007 & 0,404 & 0,186 & 0,007 & 0,085 & 0,056 \\
\hline B16 & 0,042 & 0,264 & 0,130 & 0,003 & 0,058 & 0,047 \\
\hline M01 & 0,015 & 0,127 & 0,060 & 0,001 & 0,026 & 0,021 \\
\hline M02 & 0,047 & 0,176 & 0,116 & 0,002 & 0,039 & 0,034 \\
\hline Média & 0,021 & 0,224 & 0,109 & 0,003 & 0,047 & 0,038 \\
\hline
\end{tabular}

A comparação das posições em relação à posição de coordenada média é importante para verificar a magnitude da variabilidade das leituras, porém não é suficiente para indicar a exata acurácia do sistema, uma vez que esta deve indicar a habilidade que o equipamento possui em fornecer os valores exatos de posição em relação a posição real. Assim sendo, os mesmos parâmetros estatísticos utilizados anteriormente para se comparar as distâncias entre posições individuais e a posição média foram utilizados para se comparar cada leitura de posição com sua posição real, conforme ilustra a Tabela 11.

Tabela 11. Comparaçăo das distâncias $(\mathrm{m})$ entre posições individuais indicadas pelo GPS e a respectiva posiçăo real, obtida com distanciómetro eletrônico por métodos topográficos convencionais.

\begin{tabular}{c|c|c|c|c|c|c}
\hline Ponto & Mínima & Máxima & Média & Variância & $\begin{array}{c}\text { Desvio } \\
\text { Padrăo }\end{array}$ & $\begin{array}{c}\text { Desvio } \\
\text { Médio }\end{array}$ \\
\hline B00 & 0,394 & 1,236 & 0,769 & 0,051 & 0,219 & 0,184 \\
\hline B05 & 0,649 & 0,986 & 0,831 & 0,009 & 0,095 & 0,081 \\
\hline B07 & 0,541 & 0,875 & 0,660 & 0,006 & 0,073 & 0,060 \\
\hline B08 & 0,357 & 0,481 & 0,414 & 0,001 & 0,036 & 0,030 \\
\hline B09 & 0,624 & 0,783 & 0,689 & 0,002 & 0,047 & 0,039 \\
\hline B10 & 0,474 & 0,666 & 0,528 & 0,001 & 0,038 & 0,026 \\
\hline B13 & 1,042 & 1,578 & 1,261 & 0,015 & 0,122 & 0,097 \\
\hline B14 & 0,052 & 0,510 & 0,305 & 0,013 & 0,110 & 0,092 \\
\hline B16 & 0,303 & 0,599 & 0,436 & 0,007 & 0,086 & 0,072 \\
\hline M01 & 0,064 & 0,186 & 0,119 & 0,001 & 0,036 & 0,032 \\
\hline M02 & 0,676 & 0,924 & 0,784 & 0,005 & 0,070 & 0,062 \\
\hline Média & 0,431 & 0,735 & 0,566 & 0,009 & 0,078 & 0,065 \\
\hline
\end{tabular}


Pode-se verificar que em média, considerando-se todos os 11 pontos do ensaio, a menor erro de leitura em relação à posição real foi de $0,431 \mathrm{~m}$. $O$ erro médio global de posicionamento foi de $0,566 \mathrm{~m}$. O máximo erro de posicionamento foi de $1,578 \mathrm{~m}$, obtido no ponto B13.

Graficamente, a dispersão dos dados pode ser mais facilmente visualizada. Assim, para cada um dos 11 pontos considerados foi elaborado um gráfico no qual foram plotados todos os 59 pontos, cujos valores de longitude foram representados no eixo $x$ e os valores de latitude no eixo $y$, conforme ilustra a Figura 11, a qual apresenta as coordenadas obtidas com o GPS para o ponto B00.

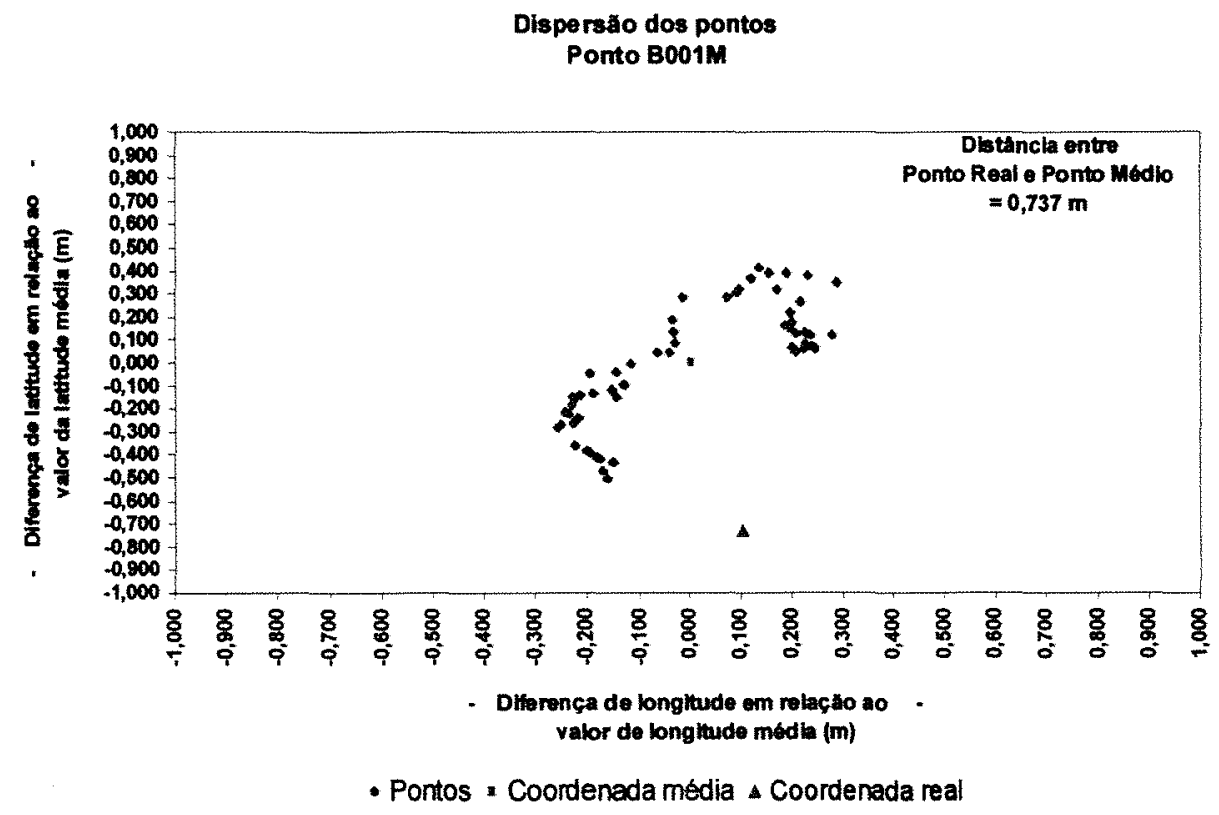

Figura 11. Dispersão dos pontos obtidos pelo GPS.

\subsection{Posicionamento da colhedora.}

A fim de verificar a eficácia da correção diferencial dos dados de posição, foram elaborados, conforme descrito anteriormente, gráficos 
relacionando longitude, representada no eixo $x$ e latitude, representada no eixo y, conforme ilustra a Figura 12, a qual apresenta o conjunto de posições coletadas em campo pela colhedora em operação no talhão 1. Cada linha representada no gráfico refere-se a uma passagem da colhedora em operação. Nota-se que as linhas são relativamente paralelas, não existindo sobreposição entre elas. Pode-se verificar também que o conjunto de todas as linhas apresentam uma forma bastante semelhante ao formato da figura do talhão 1, ilustrado no croqui da área (Figura 4 do item 3.1.1.).

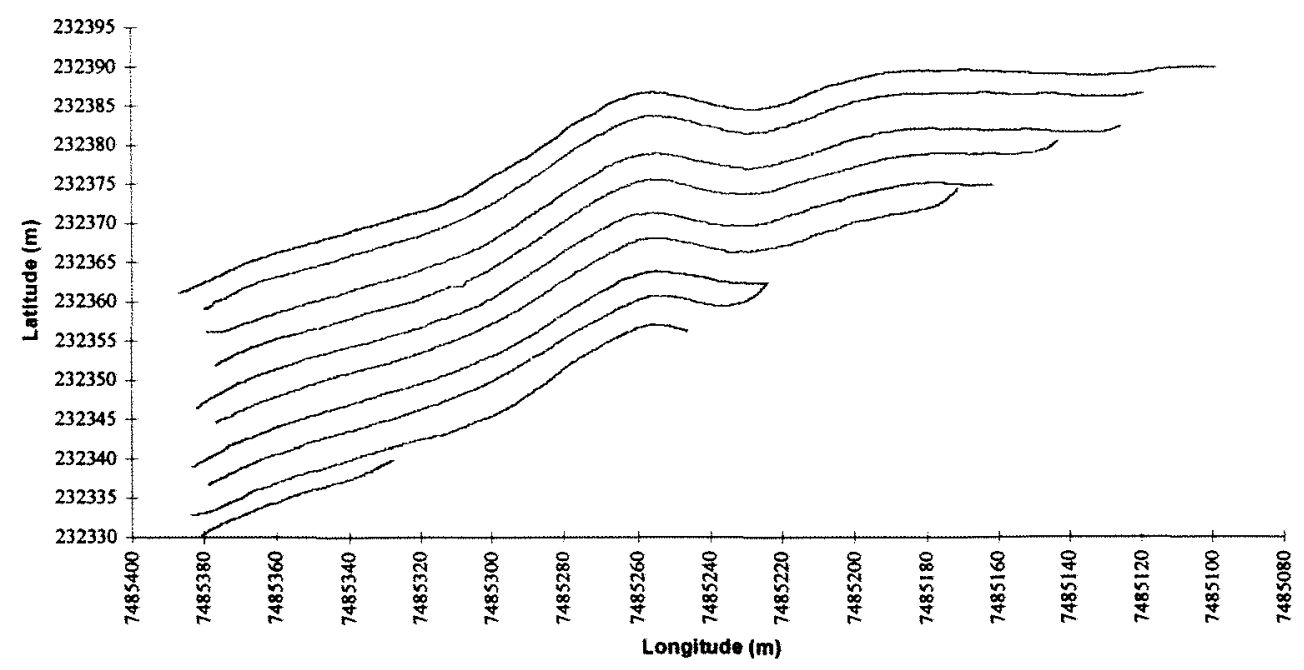

Figura 12. Representação gráfica das coordenadas geográficas, longitude e latitude, coletadas durante a operação de colheita para o talhão 1 . Verificação da eficácia da correção diferencial dos dados de posiçăo fornecidos pelo GPS.

Além da eficácia da correção diferencial, a própria acurácia do sistema de GPS pode ser visualmente verificada pela análise da Figura 12. Sendo a largura efetiva da plataforma de $3,6 \mathrm{~m}$, cada passada paralela ocorria em distâncias de iguais a $3,6 \mathrm{~m}$. Assim sendo, se os erros de posicionamento do GPS fossem superiores a esta largura, seria possível se verificar a sobreposição das linhas de colheita. 


\subsection{Peso acumulado de grãos.}

A quantidade de grãos colhidos e armazenados temporariamente no interior do sub-tanque graneleiro aumentava gradativamente com 0 deslocamento da colhedora, conforme ilustra a Figura 13. A linha contínua representa os valores de peso coletados ponto a ponto em uma passada da máquina colhendo 4 linhas de milho, Os quadros representam os valores calculados de peso em intervalos de 10,8 em $10,8 \mathrm{~m}$, conforme metodologia apresentada anteriormente.

Pode-se verificar através do gráfico ilustrado na Figura 13 que a metodologia utilizada para minimizar os erros momentâneos de leitura de peso, causados pelas vibrações a que estava sujeita a colhedora, enquanto em operação, foi bastante eficaz.

Devido a estas vibrações, alguns valores de peso indicados podiam ser ligeiramente inferiores ao valor instantaneamente anterior, o que representaria um decréscimo de peso e consequentemente uma produtividade negativa, fato este notoriamente impossivel. Pode-se notar

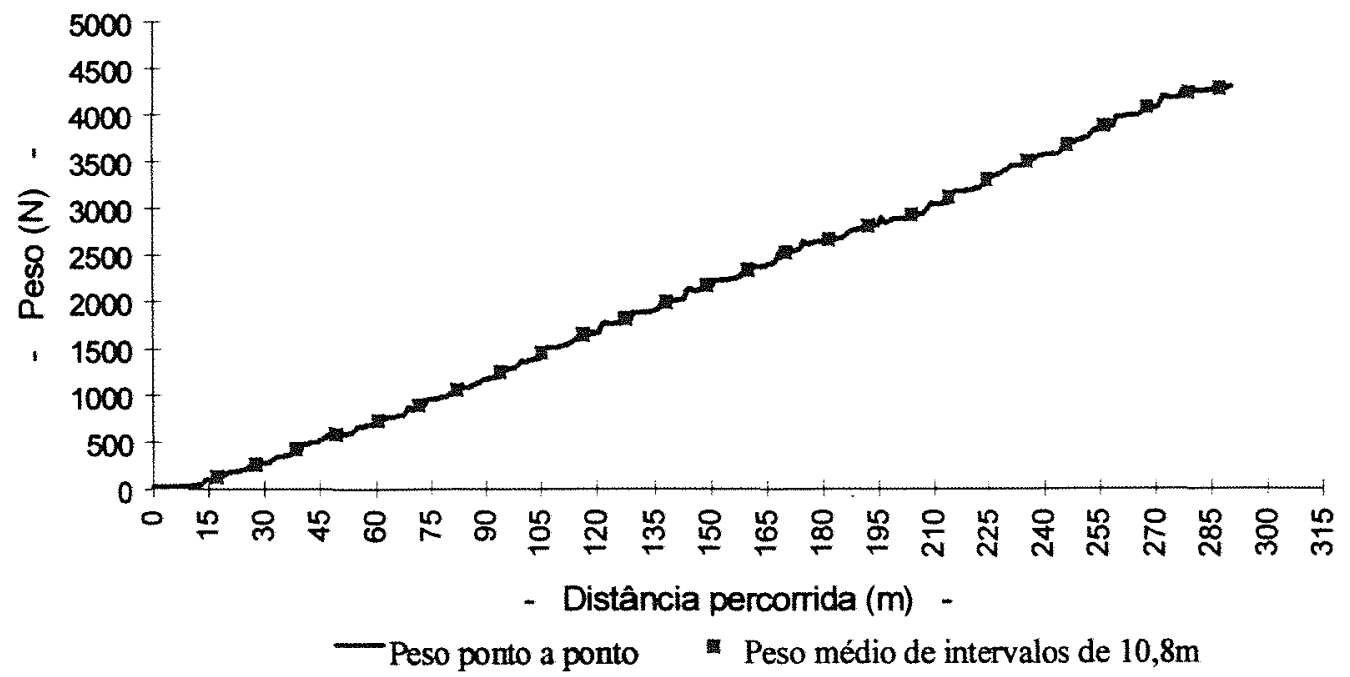

Figura 13. Peso acumulado no interior do sub-tanque graneleiro em função da distância percorrida pela colhedora. Peso médio obtido em intervalos constantes de $10,8 \mathrm{~m}$. 
que os pontos distintos representados no gráfico da Figura 13 , os quais representam os valores de pelo acumulado de grãos no sub-tanque graneleiro são sempre crescentes,

\subsection{Mapeamento da produtividade da cultura.}

A cada uma das células criadas, identificada pelas coordenadas geográficas de seu centro, foi determinada a produtividade correspondente, formando-se assim uma banco de dados contendo os valores de latitude, longitude e produtividade correspondente, conforme ilustra a Tabela 12.

Tabela 12. Dados de posiçăo e produtividade calculados para cada uma das células, a partir dos quais foram elaborados os mapas de produtividade.

\begin{tabular}{c|c|c}
\hline $\begin{array}{c}\text { Longitude } \\
(\mathrm{m})\end{array}$ & $\begin{array}{c}\text { Latitude } \\
(\mathrm{m})\end{array}$ & $\begin{array}{c}\text { Produtividade } \\
(\text { tha })\end{array}$ \\
\hline $7.485 .368,970$ & $232.364,677$ & 3,098 \\
\hline $7.485 .358,304$ & $232.366,373$ & 3,959 \\
\hline $7.485 .347,607$ & $232.367,862$ & 4,326 \\
\hline $7.485 .336,904$ & $232.369,302$ & 3,933 \\
\hline $7.485 .326,197$ & $232.370,717$ & 3,902 \\
\hline $7.485 .315,493$ & $232.372,154$ & 4,383 \\
\hline $7.485 .304,960$ & $232.374,535$ & 4,571 \\
\hline $7.485 .294,520$ & $232.377,298$ & 4,806 \\
\hline $7.485 .284,174$ & $232.380,394$ & 5,016 \\
\hline$\ldots$ & & \\
\hline
\end{tabular}

Inicialmente, os valores de produtividade de todas as células foram sub-divididos em 5 diferentes intervalos, sendo que para cada deles foram atribuídas diferentes cores, como mostra a Tabela 13. Após a definição dos intervalos, foram determinados o número de células cuja produtividade encontrava-se no referido limite, tendo-se desta forma uma estimativa da área total e do número de células associadas à cada intervalo definido. 
Tabela 13. Intervalos de produtividade considerados para a elaboração do mapa de produtividade.

\begin{tabular}{c|c|c|c|c}
\hline \multirow{2}{*}{$\begin{array}{c}\text { Produtividade } \\
\text { (t/ha) }\end{array}$} & \multicolumn{2}{|c|}{ Freqüência (\%) } & \multicolumn{2}{c}{ Células } \\
\cline { 2 - 5 } & Parcial & Acumulada & No no intervalo & Cor \\
\hline $\mathbf{2} \mathbf{2 , 4 1}$ & $9,75 \%$ & $9,75 \%$ & 108 & \\
$\mathbf{2 , 4 1}$ a 3,59 & $24,10 \%$ & $33,84 \%$ & 267 & \\
$\mathbf{3 , 5 9}$ a 4,76 & $56,23 \%$ & $90,07 \%$ & 623 & \\
$\mathbf{4 , 7 6}$ a 5,94 & $9,39 \%$ & $99,46 \%$ & 104 & \\
$\geq \mathbf{5 , 9 4}$ & $0,54 \%$ & $100,00 \%$ & 6 & \\
\hline Total & --- & - & $\mathbf{1 1 0 8}$ & \\
\hline
\end{tabular}

A partir dos dados de produtividade e posição, e com base nas classes de produtividade indicadas, foi criado o mapa da produtividade, conforme ilustra a Figura 14.

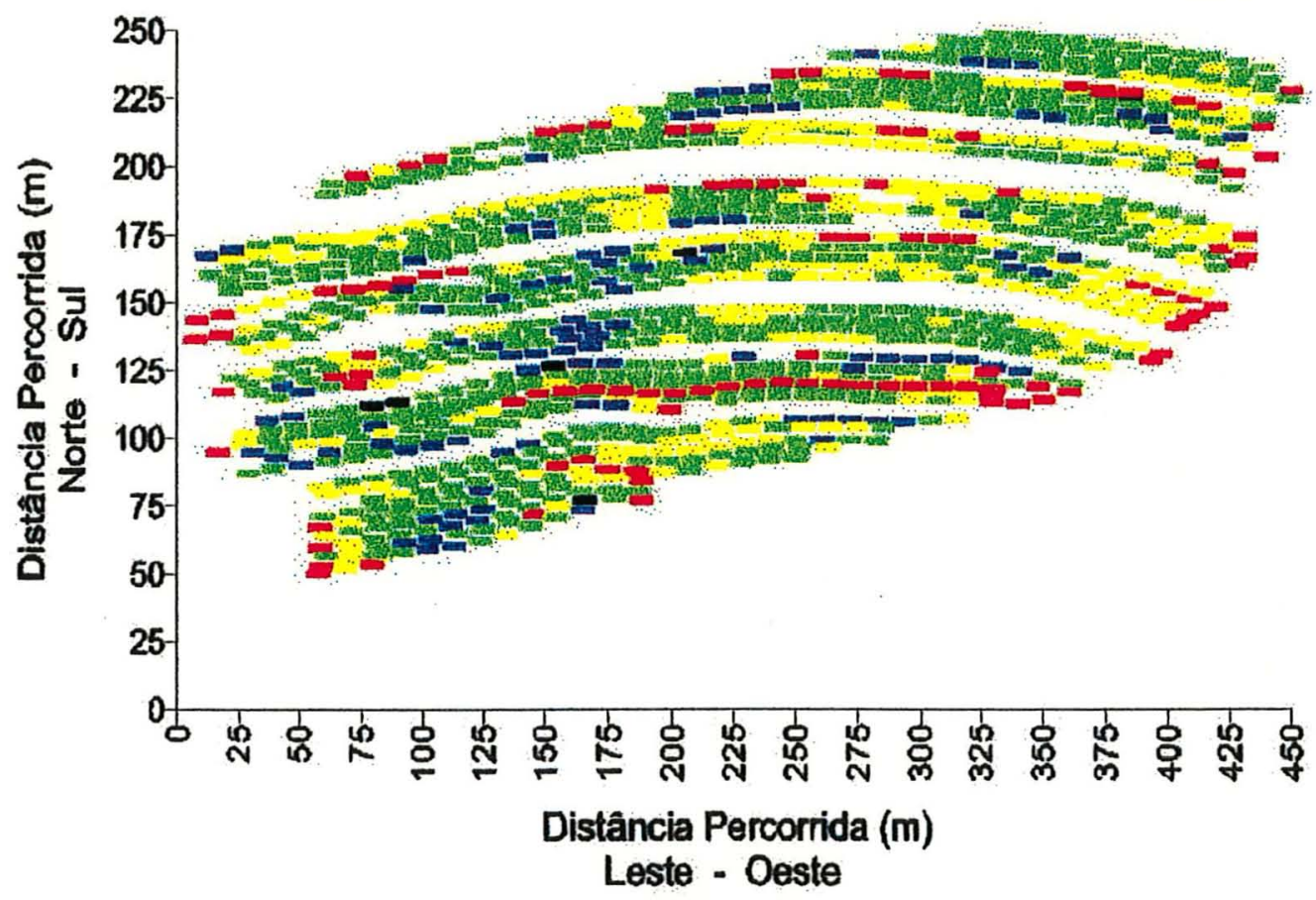

\section{Legenda}

\begin{tabular}{c|c|c}
\hline Intervalo & Freqüência & Cor \\
\hline$\leq \mathbf{2 , 4 1}$ & $9,75 \%$ & \\
$\mathbf{2 , 4 1}$ a 3,59 & $24,10 \%$ & \\
$\mathbf{3 , 5 9}$ a 4,76 & $\mathbf{5 6 , 2 3 \%}$ & \\
$\mathbf{4 , 7 6}$ a $\mathbf{5 , 9 4}$ & $9,39 \%$ & \\
$\geq \mathbf{5 , 9 4}$ & $0,54 \%$ & \\
\hline
\end{tabular}

Figura 14. Mapa de produtividade da cultura de milho. 
Nota-se na Figura 14 que cada uma das células é representada individualmente. Os mapas discretizados de produtividade são particularmente úteis pois permitem a realização de uma série de análises individuais, como por exemplo a ocorrência de alguns tipos de erros. Nota-se que nenhuma célula foi representada fora ou longe da área física, o que poderia ocorrer caso existissem erros na determinação das coordenadas da célula, seja por erro no processamento dos dados, ou por falha no equipamento de posicionamento geográfico. Neste caso, células isoladas apareceriam fora da área real.

A existência de células adjacentes que apresentem valores de produtividades extremamente diferentes podem representar algum tipo de problema ou erro do sistema de medição, principalmente relacionado à acurácia da medição da produtividade, embora estas situações possam ocorrer.

Uma visão mais detalhada dos valores de produtividade dentro das classes consideradas pode ser verificada através da análise do gráfico ilustrado na Figura 15, o qual apresenta a freqüência da ocorrência de cada uma das 5 classes de produtividade definidas. Pode-se notar que 56,23\%

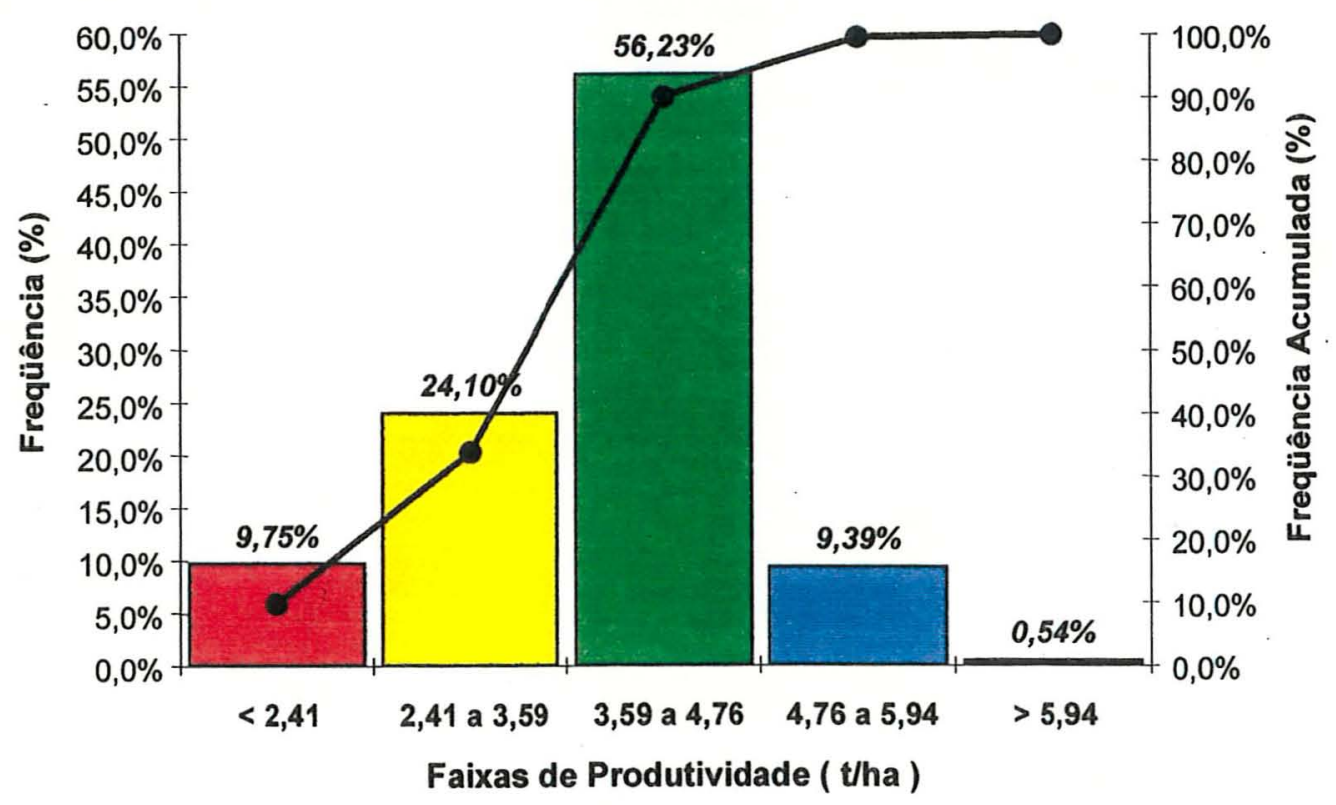

Figura 15. Distribuição da produtividade da cultura do milho para a área mapeada. 
das células, representadas pela cor verde, apresentaram produtividades entre 3,59 t/ha e 4,76 ha. Apenas $9,93 \%$ das células, representadas pelas cores azul e preto, mostraram valores acima de 4,76 tha e para toda a área, uma produtividade média de 3,76 tha

Conforme discutido anteriormente, os mapas que apresentam as células de forma discretizada possuem utilidades, porém não proporcionam uma visão clara da variabilidade espacial da produtividade. Assim, a elaboração de mapas de isoprodutividade, obtidos a partir da interpolação dos dados originais torna-se particularmente interessante.

Os dados originais de posição e produtividade foram então interpolados através de triangulação linear, gerando-se o mapa ilustrado na Figura 16. Pode-se verificar, a partir da análise deste mapa, a ocorrência de regiões bem definidas cuja produtividade baixa, entre 2,41t/ha e 3,59t/ha, representadas pela cor amarela. Nota-se ainda a ocorrência de algumas poucas áreas, representadas pela cor azul, cujos valores de produtividade

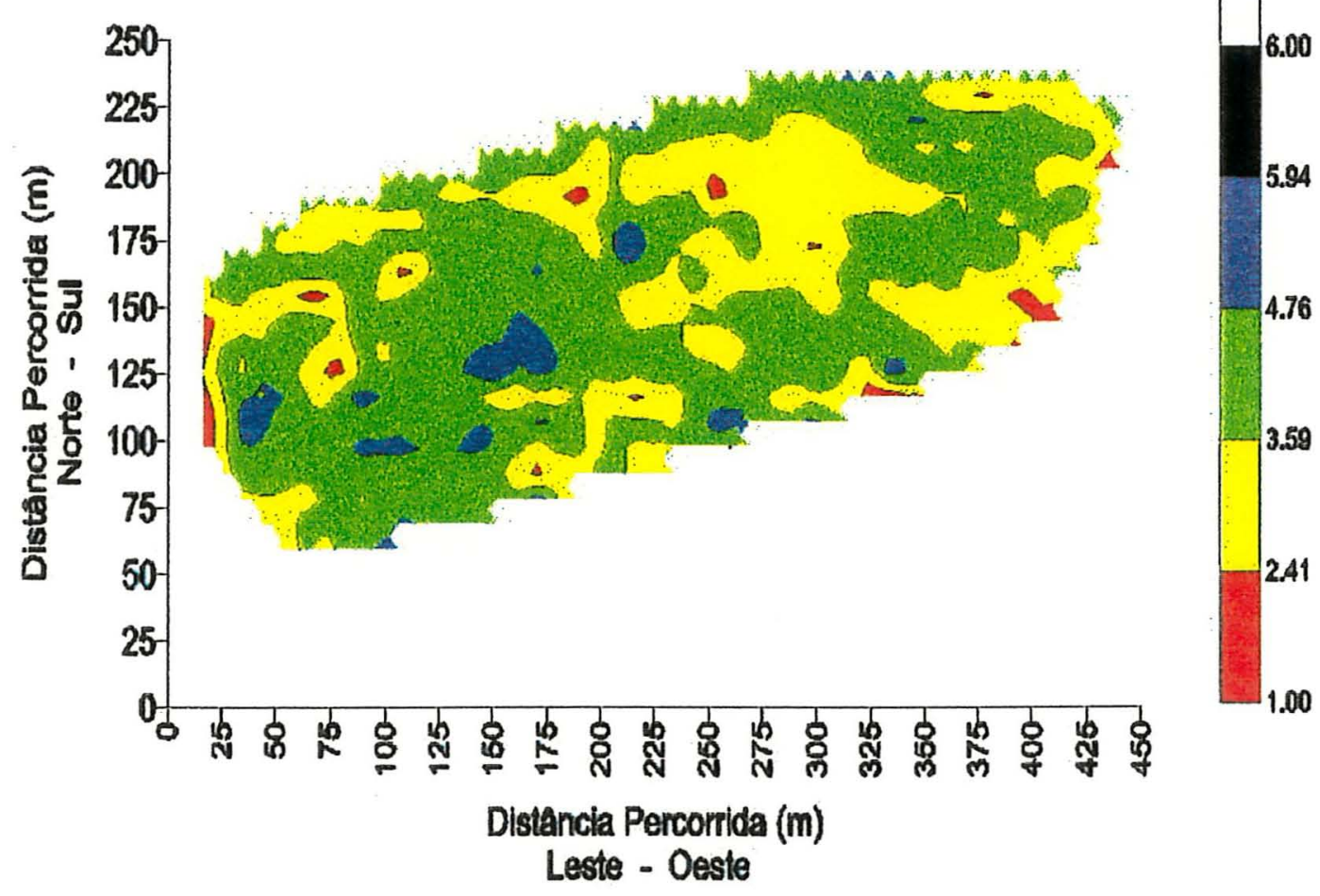

Figura 16. Mapa de isoprodutividade obtido para a cultura do milho. 
foram superiores a 4,76 t/ha.

Através da análise dos mapas de isoprodutividade podem ser identificadas as áreas de mais baixa produtividade, representadas pelas regiões de cor vermelha.

Uma vez identificadas as regiōes de baixa produtividade, pode-se com o auxilio de um receptor de GPS, voltar ao campo a fim de se verificar os fatores que contribuíram para limitar a quantidade de grãos produzidos. Estes mapas representam, portanto, informações indispensáveis para o processo de tomada de decisão, necessárias em uma atividade agrícola profissional. 


\section{CONCLUSÕES.}

O sistema automático de medição da produtividade desenvolvido neste trabalho apresentou excelente acurácia, permitindo a quantificação precisa da variação espacial da quantidade de grãos colhidos ao longo da área, através da indicação direta do peso acumulado de grãos colhidos.

A determinação da posição geográfica da colhedora foi realizada de forma satisfatória, sendo que o sistema de GPS utilizado apresentou a acurácia suficiente para o mapeamento da produtividade, estando os erros de posicionamento em níveis compativeis com os erros encontrados na bibliografia descrita.

A correção diferencial de posicionamento, realizada em pós processamento foi eficaz na correção diferencial das coordenadas geográficas indicadas pelo receptor móvel de GPS.

O receptor móvel do GPS, utilizado como coletor de dados, mostrouse adequado para a aquisição de dados de peso. A principal limitação do receptor enquanto sistema de aquisição de dados refere-se ao fato deste possuir apenas uma única entrada serial, permitindo assim que apenas um único parâmetro possa ser lido.

Os sistemas de filtragem analógica e digital utilizados foram indispensáveis para 0 mapeamento da produtividade, apresentando resultados satisfatórios na minimização dos erros devidos as vibrações a que a colhedora estava sujeita durante a operação.

Os softwares utilizados para a elaboração dos mapas de produtividade mostraram-se adequados para a aquisição e processamento dos dados, bem como para a confeç̧ão dos mapas de produtividade.

O sistema automático de medição da produtividade, após algumas modificações e adaptações, poderá ser utilizado para o mapeamento de 
outras culturas cujas características não permitam a utilização de sensores de fluxo de massa ou volumétricos.

Os mapas de produtividade elaborados no trabalho permitiram que a variabilidade espacial da produtividade da cultura do milho fosse identificada e quantificada. 


\section{BIBLIOGRAFIA CITADA.}

AUERNHAMMER, H.; DEMMEL, M.; MUHR, T.; ROTTMEIER, J.; WILD, K. GPS for yield mapping on combines. Computers and Eletronics in Agriculture, v.11, p.53-68, 1994.

BAERDEMAEKER, J. De; DELCROIX, R.; LINDEMANS, P. Monitoring the grain flow on combines. In: AGRI-MATION CONFERENCE AND EXPOSITION, 1., Chicago, 1985, Agri-Mation 1: proceedings, St. Joseph; ASAE, 1985, p.329-337.

BALASTREIRE, L.A. Aplicação localizada de insumos - ALI: Um velho conceito novo. In: CONGRESSO BRASILEIRO DE ENGENHARIA AGRÍCOLA, 23. Anais, Campinas: UNICAMP, 1994, p.248. (resumo).

BIRREL, S.J.; SUDDUTH, K.A.; BORGELT, S.C. Comparison of sensors and techniques for crop yield mapping. Computers and Eletronics in Agriculture, v.14, p.215-233, 1996.

BLACKMORE, B.S.; MARSHALL, C.J. Yield mapping; Erros and algorithms. In: INTERNATIONAL CONFERENCE ON PRECISION AGRICULTURE, 3., Minneapolis, 1996. Precision agriculture: proceedings. Madison: ASA; CSSA; SSSA, 1996, p.403-414.

BRESLER, E.; DASBERG, S.; RUSSO, D.; DAGAN, G. Spatial variability of crop yield as a stochastic soil process. Soil Science Society of America Journal, v.45, p.600-605, 1981. 
CAHN, M.D.; HUMMEL, J.W.; BROUER, B.H. Spatial analysis of soil fertility fo site-specific crop management. Soil Science Society of America Journal, v.58, n.4, p.1240-1248, July/Aug. 1994.

CHANCELLOR, W.J. ; GORONEA, M.A. Effects of spatial variability of nitrogen, moisture and weeds on the advantages of site-specific applications for wheat. Transactions of the ASAE, v.37, n.3, p.717-724, May/June, 1994.

CHANCELLOR, W.J.; GORONEA, M.A. Spatial variability of nitrogen, moisture and weeds. St. Joseph: ASAE, 1993, 35p. (ASAE Paper, 931069).

EVANS, R.G.; HAN, S. Mapping the nitrogen leaching potential under center-pivot irrigation. St. Joseph: ASAE, 1994a, 13p. (ASAE Paper, 942555).

EVANS, R.G.; HAN, S. Field-scale GIS soil database creation. St. Joseph: ASAE, 1994b, 23p. (ASAE Paper, 94-3078).

EVANS, R.G.; HAN, S.; RAWLINS, S.L. GIS capabilities and limitations for precision farming. St. Joseph: ASAE, 1995, 14p. (ASAE Paper, 953236).

GILBERT, C. Erros em GPS. O que você pode e o que não pode corrigir. Fator Gis, v.19, p.62-63, Maio/Junho, 1997.

GOERING, C.E. How much and where. Agricultural Engineering, v.73, n.4, p.13-15, July, 1992. 
GOERING, C.E. Recycling a concept. Agricultural Engineering, v.65, n.6, p.25, Nov. 1993.

GOERING, C.E.; HAN, S. A field information system for SSCM. Warrendale: SAE International, 1993. 6p. (SAE Technical Paper Series, 932422).

HAN, S.; HUMMEL, J.W.; GOERING, C.E.; CAHN, M.D. Cell size selection for site-specific crop management. Transactions of the ASAE, v.37, n.1, p.19-26, Jan./Feb. 1994.

HAN, S.; RAWLINS, S.L.; SCHNEIDER, S.M.; EVANS, R.G. Yield mapping with differential GPS, St. Joseph: ASAE, 1995, 6p. (ASAE Paper, PNW95-302).

HUMMEL, J.W.; GAULTNEY, L.D.; SUDDUTH, K.A. Soil property sensing for site-specific crop management. Computers and Eletronics in Agriculture, v.14, p.121-136, 1996.

KINCHELOE, S. Tools to aid management: The use of site specific management. Journal of Soil and Water Conservation, v.49, n.2, p.43-45, 1991. Special Suplement.

KRÜGER, G.; SPRINGER, R.; LECHNER, W. Global navigation satellite systems (GNSS). Computers and Eletronics in Agriculture, v.11, p.3-21, 1994. 
MOHAMED, S.B.; EVANS, E.J.; SHIEL, R.S. Mapping techniques and intensity of soil sampling for precision farming. In: INTERNATIONAL CONFERENCE ON PRECISION AGRICULTURE, 3., Minneapolis, 1996. Precision agriculture: proceedings. Madison: ASA; CSSA; SSSA, 1996, p.217-226.

PAICE, M.E.R.; MILLER, P.C.H.; DAY, W. Control requirements for spatially selective herbicide spayers. Computers and Eletronics in Agriculture, v.14, p.163-177,1996.

PEDERSEN, H.H. Site-specific farming in Denmark - research and development of decision support. In: INTERNATIONAL CONFERENCE ON COMPUTERS IN AGRICULTURE, 5., Orlando, 1994. Computers in agriculture: proceedings. St. Joseph: ASAE, 1994. p.587-591.

REITZ, P.; KUTZBACK, H.D. Data acquisition for yield mapping with combine harvesters. In: INTERNATIONAL CONFERENCE ON COMPUTERS IN AGRICULTURE, 5., Orlando, 1994. Computers in agriculture: proceedings. St. Joseph: ASAE, 1994, p.42-47.

REITZ, P. ; KUTZBACH, H.D. Investigations on a particular yield mapping system for combine harvesters. Computers and Eletronics in Agriculture, v.14, p.137-150, 1996.

SABIR, M.S.; STUCHLY, S.S.; HAMID, A. A mass flowmeter for grain. Transactions of the ASAE, v.19, n.6, p.1138-1142, Nov./Dec. 1976. 
SAUNDERS, S.P.; LARSCHEID, G.; BLACKMORE, B.S. A method for direct comparison of differential global positioning systems suitable for precision farming. In: INTERNATIONAL CONFERENCE ON PRECISION AGRICULTURE, 3., Minneapolis, 1996. Precision agriculture: proceedings. Madison: ASA; CSSA; SSSA, 1996, p.663-674.

SCHUELLER, J.K. Impediments to spatially variable field operations. Computers and Eletronics in Agriculture, v.14, p.249-253, 1996.

SEARCY, S.W. Engineering systems for site-specific management: opportunities and limitations. In: INTERNATIONAL CONFERENCE OF SITE-SPECIFIC MANAGEMENT FOR AGRICULTURAL SYSTEMS, 1995, proceedings,. Madison: ASA-CSSA-SSSA, 1995, p.603-611.

SEARCY, S.W.; SCHUELLER, J.K.; BAE, Y.H.; BORGELT, S.C.; STOUT, B.A. Mapping of spatially variable yield during grain combining. Transactions of the ASAE, v.32, n.3, p.826-829, May/June, 1989.

SEARCY, S.W.; SCHUELLER, J.K.; BAE, Y.H.; BORGELT, S.C.; STOUT, B.A.: Measurement of agricultural field location using microwave frequency triangulation. Computers and Eletronics in Agriculture, v.4, n.3., p.209-223, 1990.

STAFFORD, J.V. Essential technology for precision agriculture. In: INTERNATIONAL CONFERENCE ON PRECISION AGRICULTURE, 3., Minneapolis, 1996. Precision agriculture: proceedings. Madison: ASA CSSA; SSSA, 1996a, p.595-604. 
STAFFORD, J.V. Spatially variable field operations. Computers and Eletronics in Agriculture, v.14, p.99-100, 1996b.

STAFFORD, J.V. ; AMBLER, B. In-field location using GPS for spatially variable field operations. Computers and Eletronics in Agriculture, v.11, p.23-36, 1994.

STAFFORD, J.V.; Le BARS, J.M.; AMBLER, B. A hand-held data logger with integral GPS for producing weed maps by field walking. Computers and Eletronics in Agriculture, v.14,p.235-247, 1996.

VANSICHEN, R. ; BAERDEMAEKER, J.De A measurement technique for yield mapping of corn silage. Journal of Agricultural Engineering Research, v.55, p.1-10, 1993.

WAGNER, L.E.; SCHROCK, M.D. Yield determination using a pivoted auger flow sensor. Transactions of the ASAE, v.32, n.2, p.409-413, Mar./Apr. 1989.

YULE, I.J.; CAIN, P.J.; EVANS, E.J.; VENUS, C. A spatial inventory approach to farm planning. Computers and Eletronics in Agriculture, v.14, p.151-161, 1996. 